\title{
ESTUDIO Y ANÁLISIS DEL SUDARIO JUDÍO CONSERVADO EN EL MUSEO BÍBLICO DE LEÓN
}

\author{
STUDY AND ANALYSIS OF THE JEWISH SHROUD OF THE FIRST CENTURY \\ PRESERVED IN THE BIBLICAL MUSEUM OF LEÓN
}

\section{Alfonso SÁNCHEZ HERMOSILLA ${ }^{1}$ - Jesús GARCÍA IGLESIAS ${ }^{2}$ - María Luz MANGADO ALONSO ${ }^{3}$}

RESUMEN: El denominado "Sudario Judío del siglo I del Museo Bíblico de León" es una pieza textil de notable interés, toda vez que se ha conservado íntegra y prácticamente intacta, a pesar de su antigüedad. Su interés resulta ser mayor dado que el hallazgo de piezas textiles tan antiguas y de tales dimensiones es poco frecuente, y en buen estado de conservación aún menos.

Se trata de una pieza de lino tejida a mano, en un telar vertical, donde los hilos también han sido hilados a mano. A pesar de que macroscópicamente aparenta estar en buen estado de conservación, el estudio microscópico pone de manifiesto una contaminación por microorganismos, por lo que se aconseja mejorar las condiciones de conservación, para evitarla progresión de su deterioro con el paso del tiempo.

Presenta cierto grado de contaminación inorgánica, debida en su mayoría a partículas formadas por cristales idiomórficos de calcita, derivados de una contaminación inicial con cal que, con el tiempo, termina evolucionando in situ a carbo-

\footnotetext{
${ }^{1}$ Médico Forense. Profesor de Antropología y Genética Forense en la Universidad Católica San Antonio (Murcia). ORCID: 0000-0003-0874-8649. hubertus06@yahoo.es.

2 Catedrático del Área de Prospección e Investigación Minera, Universidad de Oviedo. ORCID: 0000-0002-0438-2611. jesgarig@uniovi.es.

${ }^{3}$ Profesora de Oriente Antiguo de la Facultad de Teología de Vitoria-Gasteiz. ORCID: 0000-00028925-0828. marialuz.mangado@yahoo.es.

Expresamos nuestro agradecimiento al Director del Museo Bíblico y Oriental de León, Don Jesús García Recio, por su colaboración para el estudio del Sudario que se conserva en el Museo. Igualmente expresamos nuestro agradecimiento a la Dra. Celia Ropero por su ayuda en los días de trabajo en la sede del Museo para la obtención de muestras y estudio del sudario; así como a los revisores anónimos por sus valiosas sugerencias, que nos han permitido mejorar el texto.
} 
nato de calcio. También encontramos partículas de cuarzo (redondeadas y angulosas), y sal microcristalina.

Las conclusiones llevan a establecer que nos hallamos ante una tela antigua y afectada de biodegradación, que ha residido en un espacio subterráneo dentro de un ámbito de clima desértico.

PALABRAS CLAVE: Sudario Judío. Estudio técnico. Museo Bíblico de León.

ABSTRACT: The denominated "Jewish Shroud of Century I of the Biblical Museum of Leon" is a textile piece of remarkable interest, since it has been preserved intact, in spite of its antiquity. Its interest turns out to be greater given that the finding of such old textile pieces and of such dimensions is rare, and in good condition even less.

It is a piece of linen woven by hand, on a vertical loom, where the threads have also been spun by hand. Although macroscopically it appears to be in a good state of conservation, the microscopic study reveals a contamination by microorganisms, so it is advisable to improve the conditions of conservation, to avoid the progression of its deterioration with the passage of time.

It presents a certain degree of inorganic contamination, due mostly to particles formed by calcite idiomorphic crystals, derived from an initial contamination with lime that, over time, ends up evolving in situ to calcium carbonate. We also find quartz particles (round and angular) and microcrystals of salt.

The conclusions lead us to establish that we are faced with an ancient and affected fabric of biodegradation, which has resided in an underground space within a desert climate environment.

KEYWORDS: Jewish Shroud. Technical Study. Biblical Museum of León.

\section{INTRODUCCIÓN}

En este trabajo exponemos el estudio de una pieza de tela conservada en el Museo Bíblico de León. Este objeto está descontextualizado porque no se tienen datos precisos sobre su origen, lugar de procedencia, finalidad, etc. Aunque se le conoce como "Sudario Judío del siglo I del Museo Bíblico de León", no se dispone de ningún dato objetivo directo que lo pueda confirmar, ni dataciones, ni contexto arqueológico, que pueda confirmar esta adscripción cronológica.

La pieza de tela forma parte del material de museo y llegó al mismo procedente de una donación ocurrida en el mismo momento en que se inauguró en el año 2009. Actualmente se conserva en los fondos del museo, enmarcado, plegado, y sin un control adecuado de las condiciones de humedad y temperatura (ver imagen 1.1).

En este trabajo se presentan los resultados del estudio macro y microscópico de este lienzo de tela, y se exponen las hipótesis hechas sobre su manufactura, finalidad, cronología, etc. 


\section{METODOLOGÍA SEGUIDA}

En primer lugar, hemos realizado un estudio morfológico de la pieza, caracterizando sus dimensiones, peso y estado de conservación (pliegues, partes deterioradas, manchas, etc.).

Luego, usando un microscopio binocular, se ha efectuado una primera observación in situ del sudario, determinado las muestras a recoger, para posteriores estudios en laboratorio; y para detectar la presencia de posibles contaminantes, orgánicos e inorgánicos. Dichos estudios se hicieron siguiendo las técnicas convencionales aplicables al estudio de tejidos antiguos (García Iglesias et al., 2007) en los laboratorios de la Universidad de Oviedo con microscopía óptica de reflexión y de transmisión y con Microscopio Electrónico de Barrido (MEB); así como también en la Universidad Católica San Antonio de Murcia (UCAM), utilizando su servicio de microscopía electrónica de barrido (MEB).

El microscopio binocular empleado fue un NIKON, modelo SMZ1000, dotado de cámara digital de la misma casa, modelo DSFi1. Mientras que para la microscopía óptica de transparencia se utilizó un microscopio de la casa LEICA, modelo DMLP. Para el estudio de Microscopía Electrónica de Barrido se han utilizado el microscopio modelo MERLINTM, de la casa Carl Zeiss Microscopy, S. L., existente en la UCAM, así como un modelo JEOL-6610LV, de la Universidad de Oviedo.

\section{ESTUDIO DEL LIENZO}

\subsection{División del lienzo en zonas}

Una vez desplegado el lienzo para observación de sus características morfológicas, se estableció una división en zonas, tal como refleja la imagen 1.2.
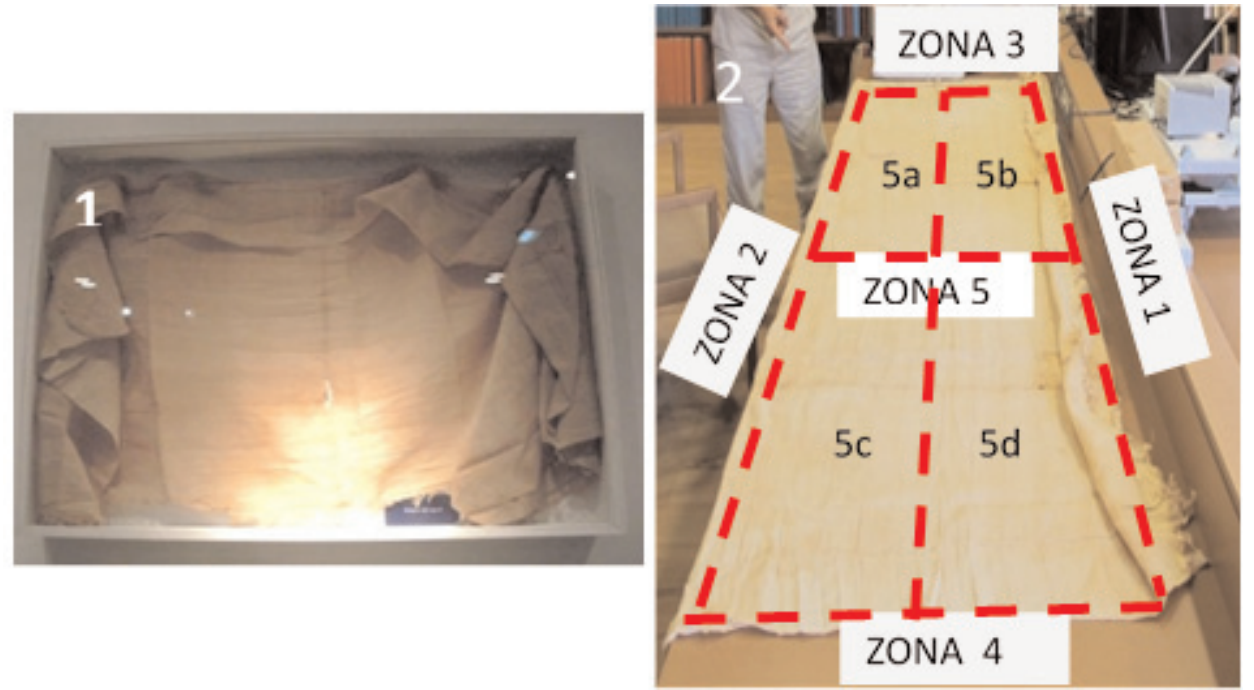

Imagen 1

Fotografía 1: El Sudario de León en su vitrina, mostrando su anverso. Fotografía 2: Zonas en las que se ha subdividido el lienzo, visto por su anverso. 


\section{Zona 1}

La zona 1 corresponde al lado inferior del sudario expuesto en su vitrina. Es el único borde del lienzo que presenta flecos, existiendo estos en toda su longitud $(230,30 \mathrm{~cm})$. Los flecos fueron añadidos al tejido una vez confeccionado este (ver imágenes 2 y 3 ).
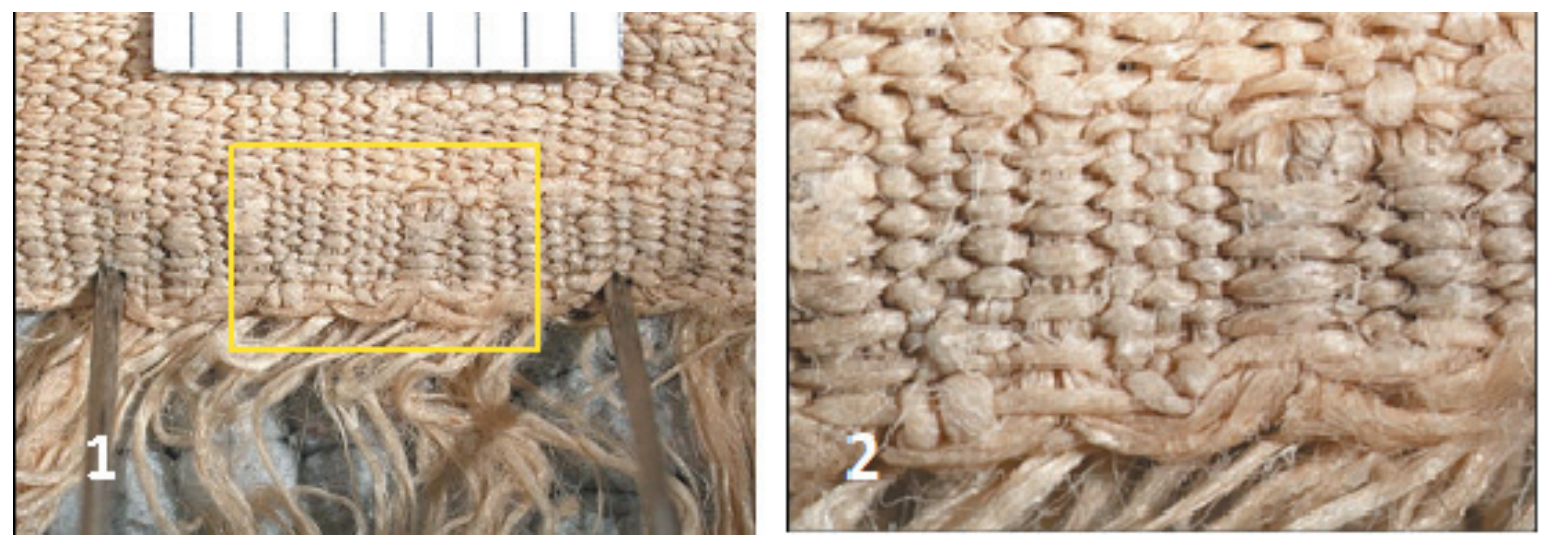

Imagen 2

Detalles del borde inferior del sudario, visto por su anverso.

Muestra una falsa cenefa provocada por la inserción de los flecos, que se introducen desde el orillo siguiendo hilos de urdimbre.

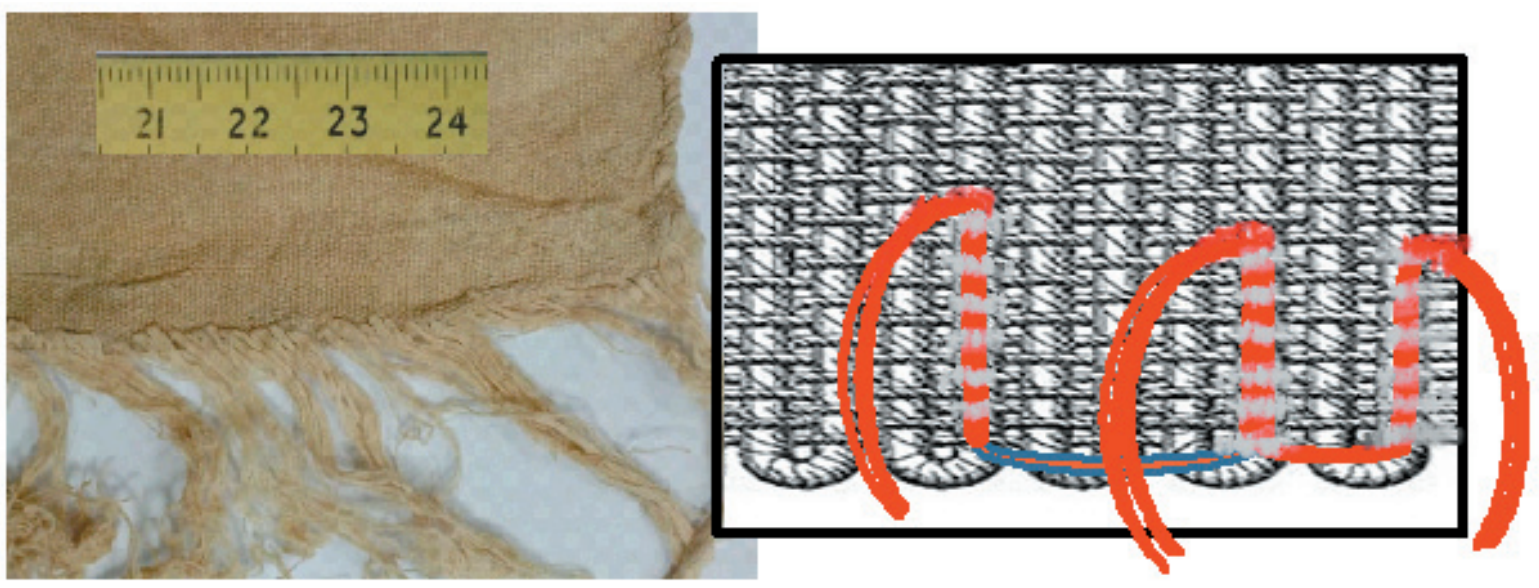

Imagen 3

Flecos emergiendo por el reverso del sudario con esquema representativo del modelo de inserción. No siguen una pauta regular, ni en la altura del punto de emergencia de los flecos ni en la distancia entre ellos. También hay amplia variación en la cantidad de fibras que componen cada fleco.

Los flecos están constituidos normalmente por haces de fibras sueltas que, en ocasiones, presentan aspecto enmarañado. De manera aislada, encontramos flecos que corresponden a hilos con su torsión original (imagen 4). 

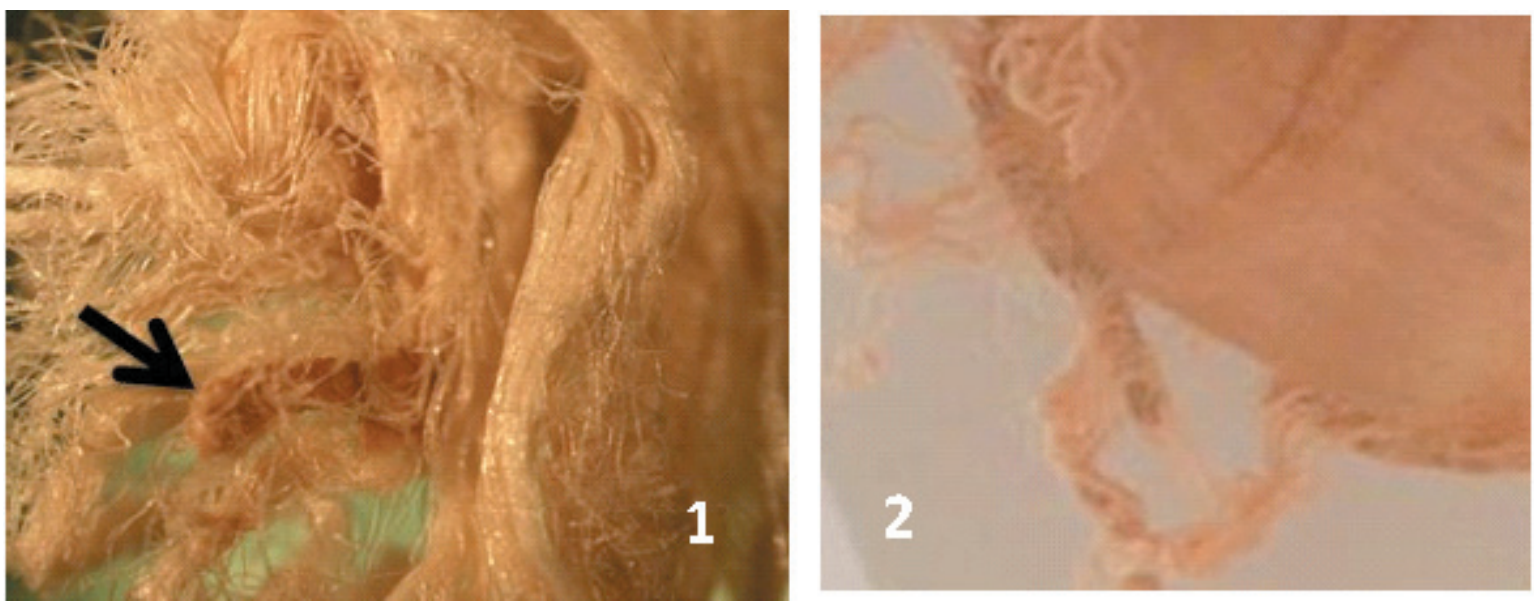

Imagen 4

Fotografía 1: Aspecto de flecos sin torsión, desordenados y enmarañados (se señala un hilo con torsión, que fue usado para formar flecos).

Fotografía 2: La falsa cenefa rompe en su límite, por el diferente comportamiento mecánico entre cenefa (densa y rígida) y el resto del tejido (más ligero y flexible).

\section{Zona 2}

La zona 2 corresponde al lado superior del sudario, que es el otro lado mayor. Como el inferior, está terminado con orillo, pero sin flecos. Mide unos 231,50 cm. Es el borde del sudario que presenta más arrugas que el resto, en especial en la esquina que forma con el borde derecho, las cuales producen un aparente efecto de redondeamiento (ver imagen 5.1). Las arrugas están muy marcadas y podrían indicar un uso previo como prenda de vestir.
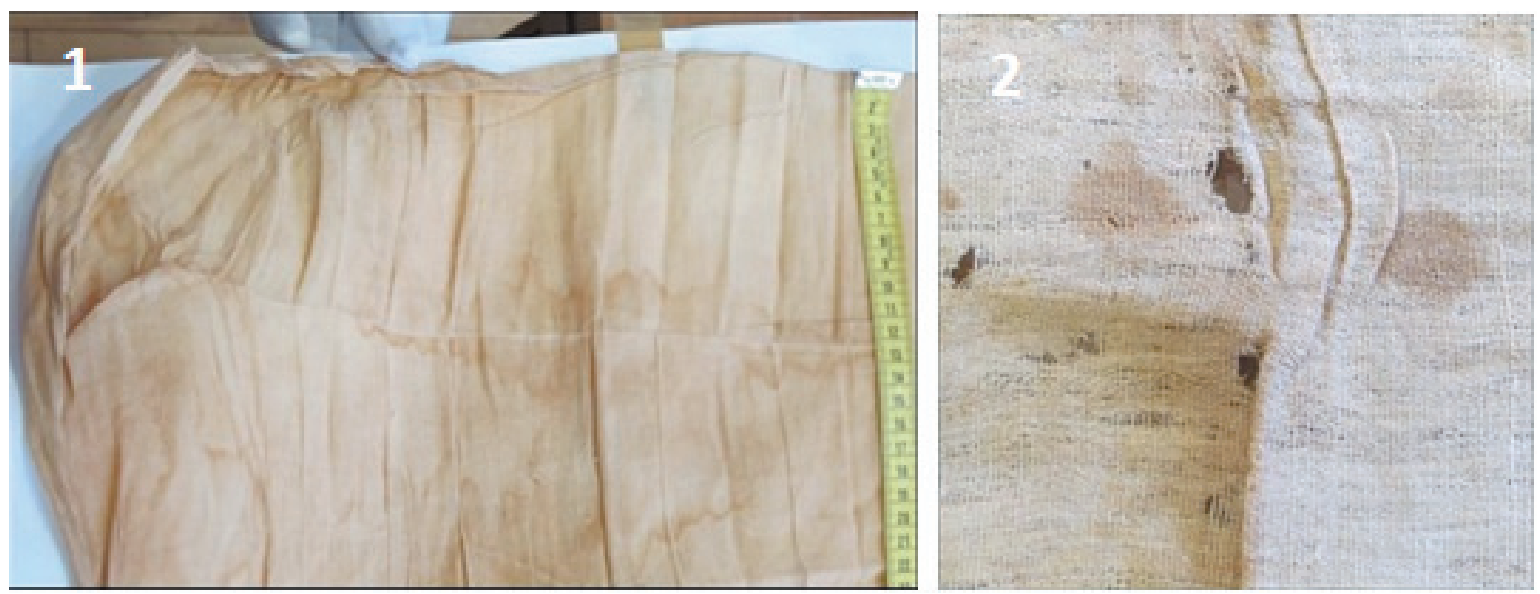

Imagen 5

Zonas del sudario manchadas con fluidos posiblemente orgánicos.

Fotografía 1: Una de las esquinas superiores del sudario, redondeada por pliegues y arrugas; los fluidos afectaron a la tela estando esta plegada.

Fotografía 2: Manchas puntiformes que se deben a gotas caídas sobre la tela plegada y horizontal; la coloración resulta compatible con un fluido hemático. 


\section{Zona 3}

Se corresponde con el lado derecho del sudario, cuando nos presenta su anverso, tal como lo vemos en su vitrina. Es también un lado recto y sin flecos, que mide aproximadamente $106 \mathrm{~cm}$, y que también está rematado con un dobladillocosido a "sobrehilo", idéntico al que vemos en la imagen 6.1; el dobladillo impide ver si la tela posee orillo o no.

El hilo empleado para el cosido del dobladillo, bastante más grueso que los hilos usados en la confección del tejido, es un hilo de muy buena calidad, que se formó usando dos hilos con torsión en $S$, que se someten ahora a contratorsión conjunta en $Z$.
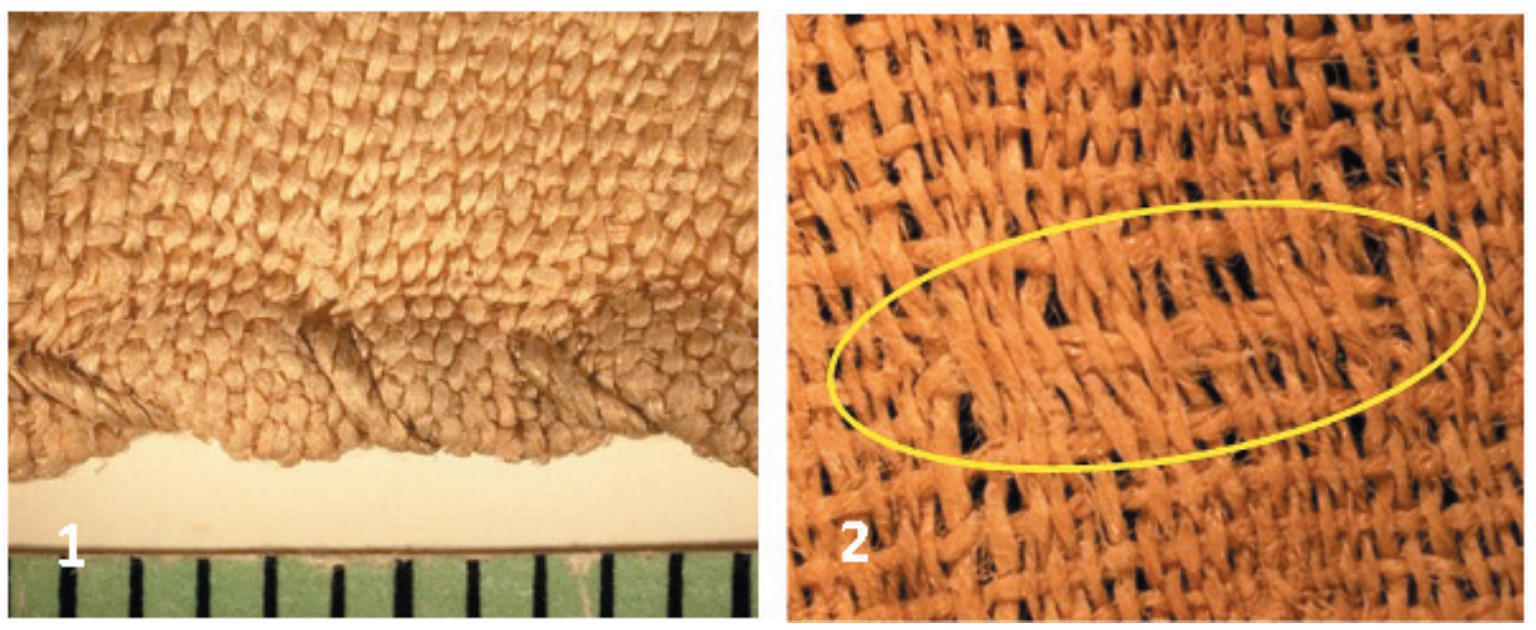

Imagen 6

Fotografía 1: Aspecto del dobladillo que remata el borde del sudario de la zona 4, y que presenta menor reflectividad. Fotografía 2: Otra zona del tejido con espaciado de hilos de trama muy desigual, y con un burdo "hilo triple" debido a error del tejedor/a.

\section{Zona 4}

Esta zona corresponde al borde derecho del sudario, tal como lo vemos expuesto en la vitrina del museo. También es un lado recto, con una longitud de unos $100 \mathrm{~cm}$. En la esquina superior se observa el redondeamiento mostrado en la imagen 5.1, que es consecuencia de arrugas y pliegues que podrían corresponder a una fase de uso como prenda personal. Dado el deterioro que muestra la tela sobre dichas arrugas y pliegues, estos serían indudablemente antiguos. Este borde muestra un remate con dobladillo sobrecosido con hilo, idéntico al que describimos en el lado opuesto (ver imagen 6), y que también aquí nos oculta si la tela se termina o no con orillo.

Tal como se ve en la fotografía de la imagen 6, la tela en la zona del dobladillo y el hilo sobrecosido tienen un color notoriamente más oscuro que el tejido inmediato. Eso indica una menor reflectividad de las fibras de lino, consecuencia del mayor deterioro mecánico que la confección del propio dobladillo causó sobre tela e hilo. 


\section{Zona 5}

Denominamos zona 5 la parte interior del conjunto del lienzo que, a su vez, se ha dividido en cuatro subzonas, tal como se muestra en la imagen 1.2:

- 5a. Esta subzona corresponde al cuadrante superior izquierdo del sudario, tal como lo mostramos extendido en la fotografía.

- 5b. Esta subzona corresponde al cuadrante superior derecho, que posee flecos en su borde de la zona 1. En esta zona se encontraron manchas aisladas de cera; así como un grupo de manchas de pequeño tamaño -entre un máximo de $2 \mathrm{~cm}$ y un mínimo de $5 \mathrm{~mm}$ de diámetro- que, por sus características organolépticas podrían resultar compatibles con gotas de fluidos cadavéricos con cierta carga hemática. Se tomaron muestras de estas manchas para su estudio.

- 5c. Esta subzona corresponde al cuadrante inferior izquierdo señalado en la imagen 1.

- 5d. Esta subzona corresponde al cuadrante inferior derecho. Posee flecos a lo largo del borde de la zona 1. En esta zona se encontraron adheridos fragmentos de suelo, que se incorporaron por contacto con presión. Ese dato podría indicar que esa zona concreta era la que quedaba expuesta en la parte inferior del sudario plegado, y la que, lógicamente, establecería contacto con el suelo, en el caso en que el sudario plegado se hubiese depositado sobre él.

Es evidente que la parte más afectada por posibles líquidos orgánicos es la superior ( 5 a y $5 b$ ); lo que parece indicar que, tal como estuvo plegada la tela, esa parte del sudario fue la que formó los pliegues superiores, siendo la más expuesta a recibir los posibles fluidos contaminantes. También podría ser la parte donde la biodegradación podría progresar, consecuentemente, de manera más fácil. De hecho, y en conformidad con lo indicado, la parte formada por los sectores $5 \mathrm{c}$ y $5 \mathrm{~d}$ presentan un grado de conservación del tejido notoriamente mejor que el que muestran los sectores $5 \mathrm{a}$ y $5 \mathrm{~b}$. Como ilustración podemos comparar la tela que vemos en la imagen 6.1, que sería representativa de la subzona $5 \mathrm{~d}$, muy poco degradada, con la tela que vemos en la fotografía de la imagen 5.2, que corresponde a una zona con manchas y con mayor degradación.

\subsection{Descripción del lienzo. Aspectos generales}

17 El tejido de nuestro sudario es de tipo tafetán. Tanto los hilos de urdimbre como los de trama muestran torsión en S. Mientras que en la urdimbre tenemos unos 17 hilos por $\mathrm{cm}$, en la trama encontramos variaciones entre 36 y 42 hilos por $\mathrm{cm}$. Estas variacionesse deben a heterogeneidad en el grosor de hilos empleados en la trama y, más especialmente, a un desigual apretado de los mismos en el propio 
telar (imagen 6.2). La heterogeneidad de grosor de hilos indicaría falta de un control de calidad del material empleado; mientras que el segundo factor -la desigual separación entre los hilos de la trama- nos indicaría un trabajo del tejedor/a poco riguroso y sistemático. El resultado final ha sido un tejido con estructura irregular y bastante abierta. El peso total del sudario es de $327 \mathrm{gr}$.

El lienzo, claramente rectangular, presenta una longitud entre 231,50 y $230,30 \mathrm{~cm}$ y una anchura entre 106 y $100 \mathrm{~cm}$. Muestra un aceptable estado de conservación, sin signos llamativos de degradación, más allá de lo esperable dada su antigüedad. Sí se observan abundantes fibras sueltas o en fase de separación de los hilos, que sirven como indicadores de cierto maltrato físico en el pasado (rozaduras, etc.). Y también encontramos agujeros en la tela, localizados principalmente en líneas de pliegues, donde el mayor rozamiento puede facilitar una mayor degradación, mecánica y biológica, de las fibras de lino.

El borde inferior del sudario es un borde con orillo, rematado con flecos. Este remate refleja una artesanía de gran calidad, realizada por consumados expertos. La existencia de flecos en el borde inferior del sudario, así como la forma rectangular y las dimensiones del mismo, permiten suponer que pueda ser una prenda femenina, confeccionada para uso a modo de chal o mantón. Esta prenda se habría confeccionado usando una pieza textil tejida a mano, que no está completa. Este dato se verifica, como veremos, al extender el dobladillo, pues los bordes laterales corresponden a cortes del tejido; lo que nos indica que la pieza tejida tenía una longitud superior a la actual, y que fue tejida, evidentemente, en un telar vertical que era bastante más largo que alto.

Las esquinas superiores del tejido presentan una disposición ligeramente redondeada (imagen 5.1), a causa de arrugas y pliegues, que podrían indicar deformaciones por uso. Pero dado el buen estado de conservación de los cuatro bordes, en donde los hilos no presentan erosión ni daño mecánico significativos, estos datos nos indicaría que, muy posiblemente, el sudario habría sido utilizado para fines funerarios habiendo tenido un escaso uso previo.

\subsubsection{Los flecos}

Los flecos que presenta el sudario en uno solo de sus lados -el inferior- constituye un rasgo singular, digno de especial atención, por razones varias: finalidad, calidad, técnica empleada, tipo de material incorporado, comportamiento ante la biodegradación, y contaminantes que lo afectan.

Aunque algunos de estos aspectos se comentan en otros apartados, creemos conveniente exponer en un apartado exclusivo el conjunto de información obtenida en el estudio de los flecos, así como las conclusiones que resultan pertinentes.

Se forman a partir de un borde con orillo, desde el que se introducen haces de fibras (y también trozos de hilos). La mayoría de estos haces (imágenes 2 a 4) care- 
cen de torsión, no solo en el tramo externo sino también en su recorrido dentro del tejido. Lo que nos indica que, para formar los flecos, generalmente no insertaron hilos con torsión, como son los que constituyen el tejido. Ocasionalmente encontramos flecos en los que se ha integrado algún hilo con torsión.

Los flecos, que se introducen a partir del orillo siguiendo hilos de urdimbre, se hacen aflorar en el reverso del sudario de forma irregular, pues los haces de fibras usados no atraviesan el mismo número de hiladas de trama, a contar desde el orillo por el que se introducen. Tampoco se observa regularidad en el espaciado entre flecos consecutivos (podemos observar de una a tres hiladas de urdimbre). Y también es variable la cantidad de fibras que componen cada fleco.

Cabe deducir que la opción de usar flecos sin torsión sea resultado de una opción puramente estética, que busca unos efectos de liviandad que no se conseguiría con flecos hechos con hilos con torsión, más densos y rígidos. Pero también esa opción puede implicar criterios económicos, por cuanto que un hilo con torsión supone más mano de obra y mayor costo.

La inserción de los flecos en el tejido genera una banda más densa y más rígi$\mathrm{da}$, de unos $5 \mathrm{~cm}$, con falso aspecto de cenefa (imagen 2). Dentro de la cenefa, obviamente, las fibras de lino han sufrido una mecanización más intensa, por lo que es lógico encontrar un descenso de su reflectividad, tal como se nos muestra en la imagen 2. Se trata del mismo efecto y la misma causa que ya observamos en los orillos. También ocurre que la cenefa, por su mayor rigidez, tiende a romper, lógicamente, en su límite con la tela normal, motivando el desprendimiento de trozos de cenefa con sus correspondientes flecos (imagen 4.2).

La calidad del excelente trabajo artesano que implican estos flecos nos aproxima más al artesano/a que confeccionó los orillos tan cuidados y regulares de los bordes izquierdo y derecho del sudario, que no al tejedor/a, un tanto descuidado, que confeccionó un tejido tan poco homogéneo como el que refleja la imagen 6.2.

Sobre las características de la biodegradación que afecta a estos flecos, remitimos a un apartado posterior, en el que ese tema se expone de manera global.

\subsubsection{Diferencias entre hilos}

Como hemos dicho, mientras que los hilos de urdimbre resultan muy homogéneos en grosor, los de trama son mucho menos homogéneos, con cambios bruscos en pasadas consecutivas, así como en el grado de torsión que presentan. Esas diferencias se explican mejor por anudado de hilos diferentes que no por variaciones longitudinales en un mismo hilo; lo que indica que en el telar se anudaban, como hilos de trama, hilos de diferentes características y procedencia. Este dato indica falta de control de calidad del hilo usado, tal vez por razones de disponibilidad en el mercado, o tal vez por meras razones de costo. 
Una referencia especial la merece el hilo con el que se sobrecose el dobladillo que remata los bordes laterales del sudario (ver imagen 6.1). Se trata de un hilo de excelente calidad, muy torsionado y de grosor muy regular, que fue confeccionado con dos hilos sencillos con torsión en $\mathrm{S}$, y a los cuales se les sometió a contratorsión en $\mathrm{Z}$ para fabricarlo. Es sin duda un hilo de calidad especial, que nada tiene que ver con los hilos de urdimbre y de trama.

\subsubsection{Los hilos dobles}

Un dato muy característico del sudario de León es la frecuencia con que encontramos "hilos dobles" en la trama (ver imágenes 7.1 y 7.2). Estos hilos dobles están formados por dos hilos normales, que discurren yuxtapuestos y paralelos, sin mostrar una segunda torsión conjunta. No son propiamente hilos dobles introducidos voluntariamente por el tejedor/a, sino que se deben a un error causado por simple descuido suyo, consistente en pasar un hilo de la trama por dos hilos consecutivos de urdimbre, en algún punto del recorrido. En ocasiones, cuando el error se produce en el borde del tejido, podría parecer que se trata de la introducción intencionada de dos hilos como hilo doble desde el orillo; pero no cabe aceptar esta hipótesis, por cuanto que no existe ninguna razón objetiva que lo justifique.
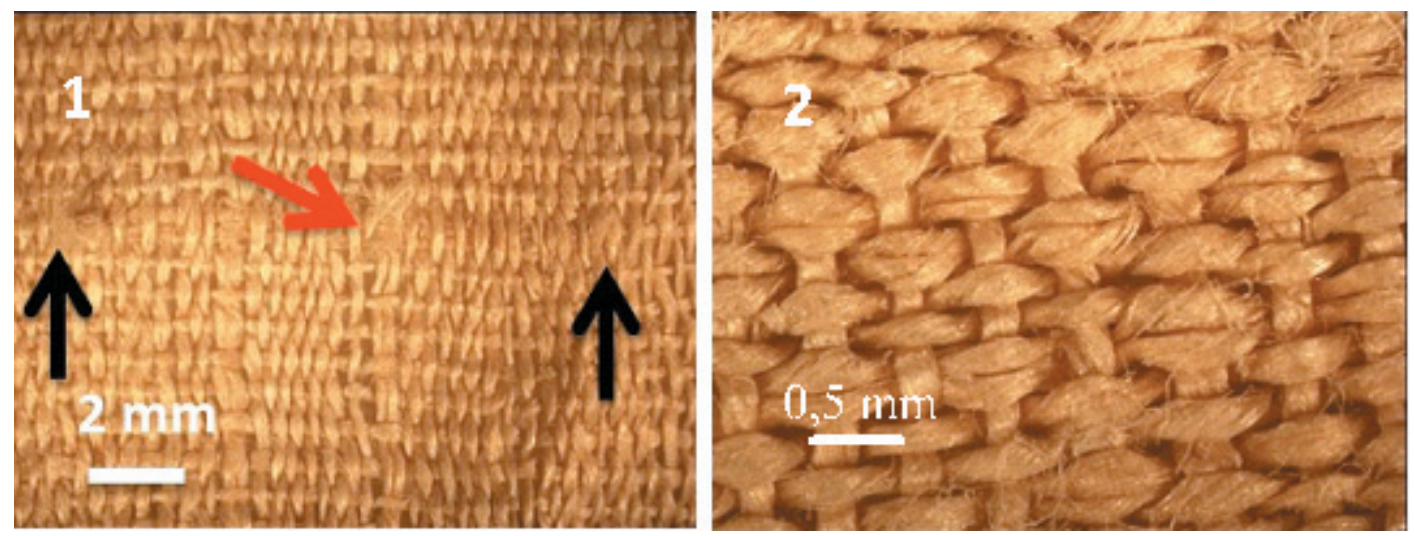

Imagen 7

Zonas del sudario bien conservadas (zona 5d). Fotografía 1: Nudo tipo en hilo de urdimbre, y con los cabos no enrollados al hilo sino dispuestos paralelos a cada lado del nudo y aflorando en sus puntos terminales (flechas negras).

Fotografía 2: Zona con abundantes hilos dobles carentes de justificación lógica.

El error del tejedor/a es más patente cuando se produce lejos del borde, tal como se observa en la imagen 10.1. De esa manera, y mientras no se corrige el error, la pasada de hilo va disponiéndose igual que la pasada anterior y generando lo que parece un hilo doble. No cabe aceptar, por tanto, que se trate de pasadas intencionadas con hilos dobles, buscando algún fin determinado; y más que denominarlos 
como "hilos dobles", que no lo son, habría que hablar de yuxtaposición de hilos normales debida a error causado por descuido del tejedor/a. La hipótesis de errores no voluntarios la refuerza la ausencia de motivos objetivos que pudiesen justificar la decisión de introducir un doble hilo, allí donde aparecen; y, por otro, la distribución aleatoria de este tipo de errores dentro de la pieza de tela con que se confeccionó el sudario (ver imágenes 10.1 y 10.2).

\subsubsection{Los nudos}

Además de los hilos dobles, otra característica singular de este tejido la constituye el hecho de presentar frecuentes nudos en hilos de trama y pocos en la urdimbre. Dadas sus características singulares, los nudos merecen un estudio particular.

34 En primer lugar, resultan indicadores evidentes de frecuentes uniones entre tramos de hilos de características muy heterogéneas (grosor, grado de torsión); lo que no ocurre en los nudos de hilos de urdimbre.

Un ejemplo de nudo tipo en hilo de urdimbre se muestra en la imagen 7.1, que corresponde a una zona del tejido bien conservada de la zona $5 \mathrm{~d}$, en la que observamos un espaciado regular de hilos bastante apretados. El nudo en hilo de urdimbre está señalado con una flecha roja. Los cabos sueltos del nudo se disponen uno a cada lado, sin enrollar al hilo y paralelos a él, hasta su terminación, señalada con las flechas negras. En ese tramo entre flechas, el hilo presenta un aspecto de hilo doble, lógicamente. El mantenimiento de los cabos sueltos en esa posición durante las sucesivas pasadas de los hilos de trama posibilita el que permanezcan ocultos, cooperando a un mejor aspecto de la tela; pero para lograrlo es evidente que se ha requerido una cooperación especial por parte del tejedor/a.

En las zonas donde el tejido presenta la regularidad que vemos en las fotografías de la imagen 7 , se contabilizan unos 35 hilos por cm en trama, y unos 15/16 hilos por $\mathrm{cm}$ en urdimbre.

En cuanto a los nudos en hilos de trama, su abundancia y el hecho de que a veces se anuden cabos de hilo de muy diferente grosor, nos lleva a la conclusión de que se trabajaba con tramos de hilos relativamente cortos, y de diferente procedencia. Conviene señalar que los cambios bruscos de grosor en hilos de trama se observan entre hilos de diferentes pasadas o entre hilos anudados; pero no a lo largo de cada tramo de hilo anudado. Insistimos en que estas características nos obligan a pensar en una falta de control de calidad en la selección de los hilos de urdimbre, con aceptación de hilos de diferente procedencia y grosor.

Una característica común de los nudos en hilos de trama la constituye el hecho de que tienen los dos cabos sueltos enrollados sobre un mismo lado del nudo, tal como vemos en las imágenes 8 y 9. Y también que los dos cabos sobrantes suelen ser mucho más largos que los de nudos en urdimbre, buscando sin duda facili- 

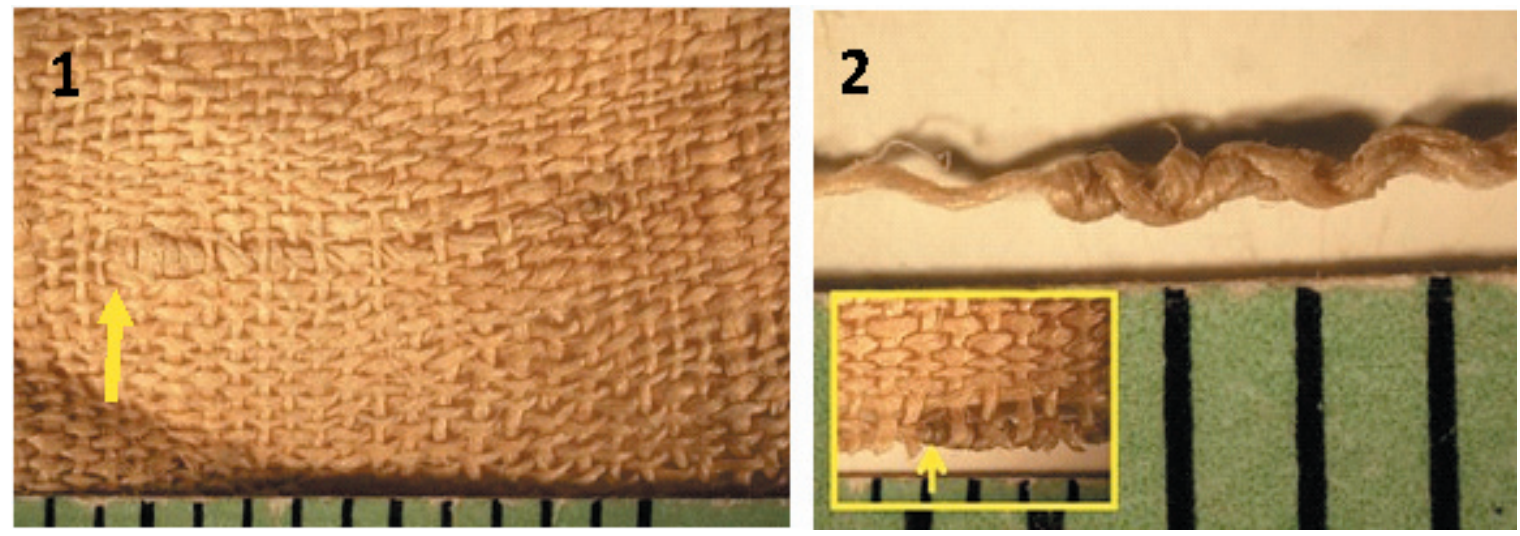

Imagen 8

Ejemplos de nudos tipo en hilos de trama. Fotografía 1: Se señala en un hilo de trama un nudo con los dos cabos enrollados a su derecha. Fotografía 2: Otro ejemplo de nudo de igual tipo, localizado en el borde de la muestra de tejido extraída; siendo notoria la baja reflectividad del hilo en la zona anudada y enrollada.

tar la estabilidad del enrollado sobre el hilo. En algún caso hemos encontrado el hecho casual de que un hilo con nudo forma parte de un hilo doble (imagen 9); pero, como sabemos, esta duplicidad es un simple indicador de error del tejedor/a.
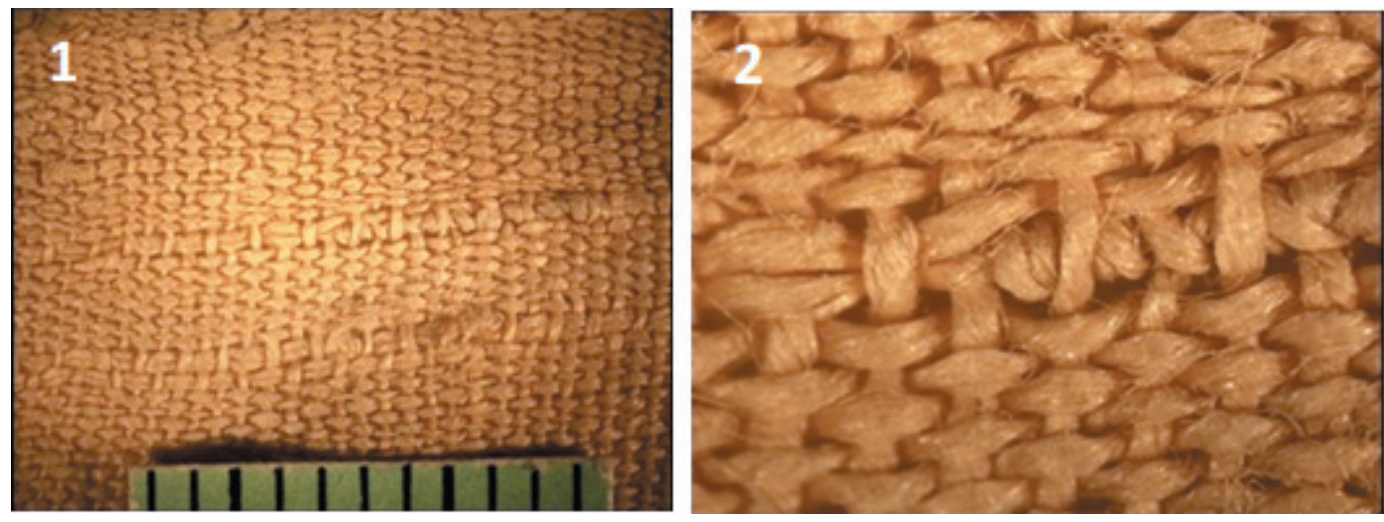

Imagen 9

Zona del tejido con algunos "hilos dobles" en la trama. En el recuadro de la fotografía 1, uno de ellos presenta también un nudo típico. En la ampliación que tenemos en la fotografía 2, se señala el nudo con flecha, y se distinguen los cabos bien enrollados a su derecha.

En un mini-telar experimental hemos verificado que, al pasar un hilo de trama con nudo, los dos cabos sueltos, estén o no enrollados, siempre se posicionan en la parte posterior del nudo, paralelos y pegados al hilo (ver imagen 10), por arrastre debido al rozamiento con los hilos de urdimbre. Consecuentemente, para producir nudos como los que encontramos en hilos de trama del sudario de León se requiere un trabajo complementario del tejedor/a, que, además de realizar el enrollado de los dos cabos en la parte posterior del nudo, debe pasar y asentar el hilo 

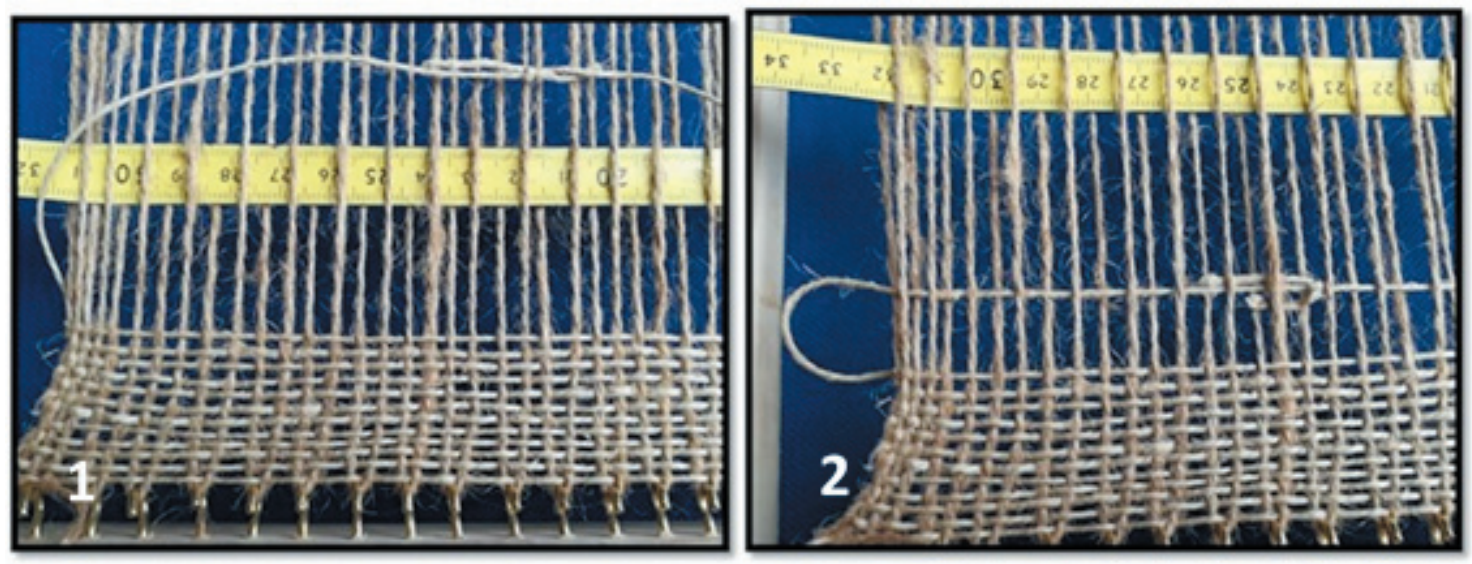

Imagen 10

En un mini-telar experimental se verificó que, al pasar hilos con nudo, los dos cabos sueltos son forzados por rozamiento a situarse detrás del nudo, paralelos al hilo. El enrollado de los cabos sueltos debería realizarse estando el hilo en su posición final, puesto que cualquier enrollado previo se deshace al pasar el hilo, por su rozamiento con los hilos de urdimbre.

evitando que el rozamiento deshaga ese enrollado; de no hacerlo, el nudo presentaría necesariamente el aspecto de la fotografía de la derecha de la imagen 10, con los cabos sueltos, paralelos y sin enrollar sobre el hilo.

Estas características de los nudos nos permiten deducir que el tejedor/a, al hacer siempre este tipo de nudos, lo que pretende es conseguir que los cabos sueltos de los nudos, tanto en urdimbre como sobre todo en trama, queden lo más ocultos posible; minimizando así el efecto estético negativo que los flecos de los nudos causarían, en el caso de aflorar y sobresalir sobre la superficie del sudario.

\subsubsection{Los pliegues}

El estudio de los pliegues que presenta el tejido (ver imágenes 1, 5 y 11) permite inferir que existió una fase de doblado en acordeón del lienzo, formando pliegues perpendiculares al eje mayor del sudario, a la que siguió otro plegado perpendicular al eje menor. Lo que determina que las marcas de los pliegues de ambos

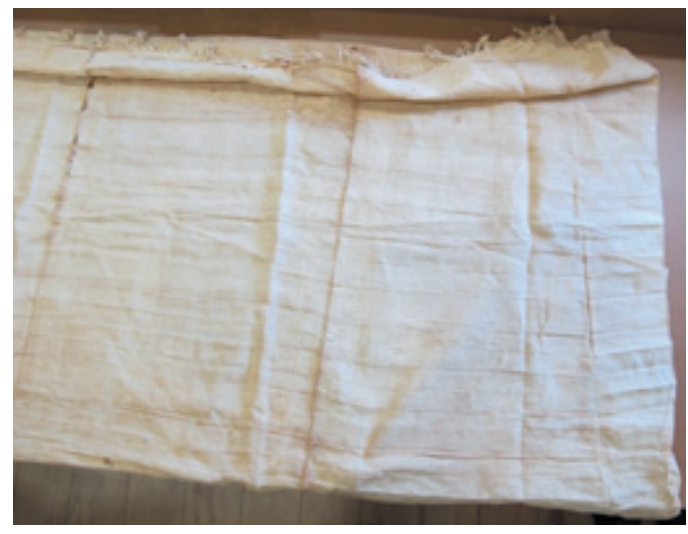
sistemas se crucen perpendicularmente.

\section{Imagen 11}

Vista de las zonas 5 c y $5 \mathrm{~d}$ del sudario, con los diferentes sistemas de pliegues.

El deterioro más intenso se produce precisamente sobre líneas verticales, más marcadas, que corresponden a los pliegues más antiguos. 
Dentro del sistema perpendicular al eje mayor, observamos dos fases de plegado de diferente importancia y antigüedad. El más antiguo presenta unas líneas de marca más fuertes y un mayor deterioro de las fibras sobre las que se asienta; y parece que pueda haberse producido teniendo un peso encima. La causa podría deberse a que, a lo largo de la historia del tejido, este se plegó de dos formas diferentes.

El sistema de pliegues perpendiculares al anterior, con líneas de plegado del tejido paralelas al eje mayor, presenta un único sistema de pliegues "en plisado"; el primero de ellos mide unos $3 \mathrm{~cm}$, y los siguientes van aumentando su tamaño de forma sucesiva. Este sistema se produce cuando la tela ya estaba plegada con el otro sistema.

Como ya se indicó (ver imagen 8), las manchas de fluidos posiblemente biológicos que presenta el sudario se produjeron estando este afectado por los dos sistemas de pliegues descritos.

\section{ALTERACIONES Y CONTAMINACIÓN DEL TEJIDO}

\subsection{La biodegradación}

El tejido presenta un buen estado de conservación, dada la edad arqueológica que se le atribuye (siglo I). También sorprende la flexibilidad de fibras e hilos, y su resistencia a romper cuando los sometemos a esfuerzos de flexión, tracción o cizalla (ver imagen 12). Ese hecho se debe sin duda a un buen estado de conservación del interior de las fibras, que muestran biodegradación exterior pero no interior (ver imágenes 15.2 y 15.3).
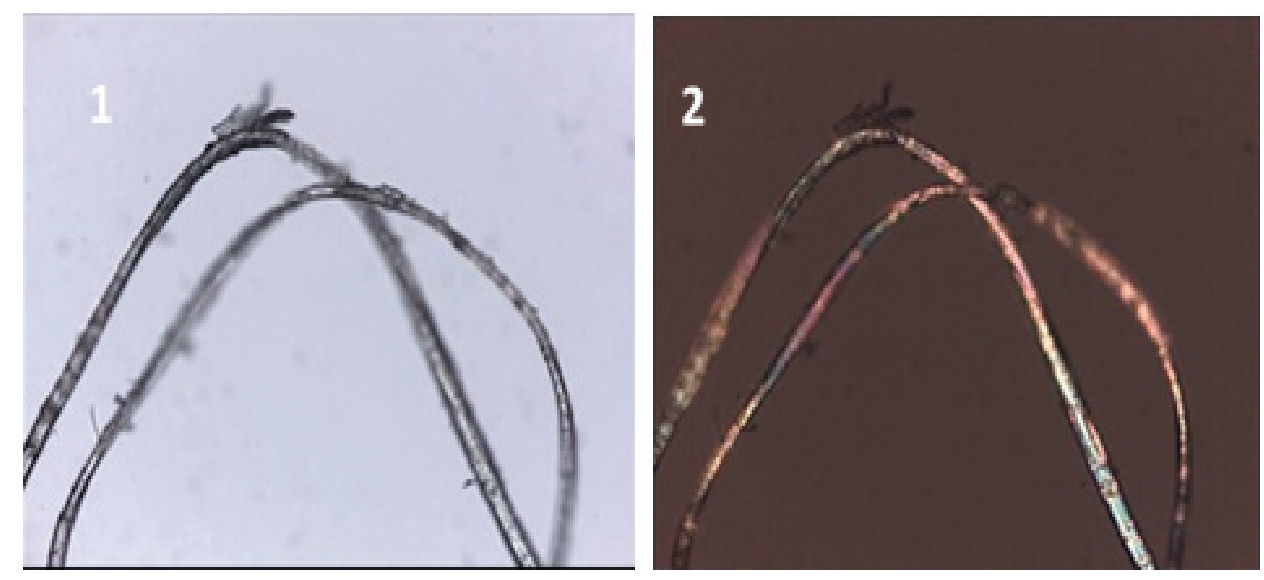

Imagen 12

Microscopio de transparencia. Fibras del sudario de León, vistas en aire, con luz normal (fotografía 1) y con luz polarizada (fotografía 2). Muestran restos de biocostra superficial aún adheridos. La difusión que sufre la luz y los colores de interferencia de bajo orden indican biodegradación. Es evidente la flexibilidad que muestran las fibras. 
Tanto las fibras de hilos del tejido como las de los flecos están muy adheridas entre sí, a causa de una sustancia ligante incolora e isótropa. Con el microscopio óptico de luz trasmitida, verificamos que esta sustancia tiene el aspecto característico de las típicas biocostras que hallamos en telas antiguas sometidas a procesos de biodegradacion (ver imágenes 12 a 14). Esas biocostras y esa biodegradación se hacen más patentes en el estudio con MEB (Microscopio Electrónico de Barrido) (ver imágenes 15 y 16).
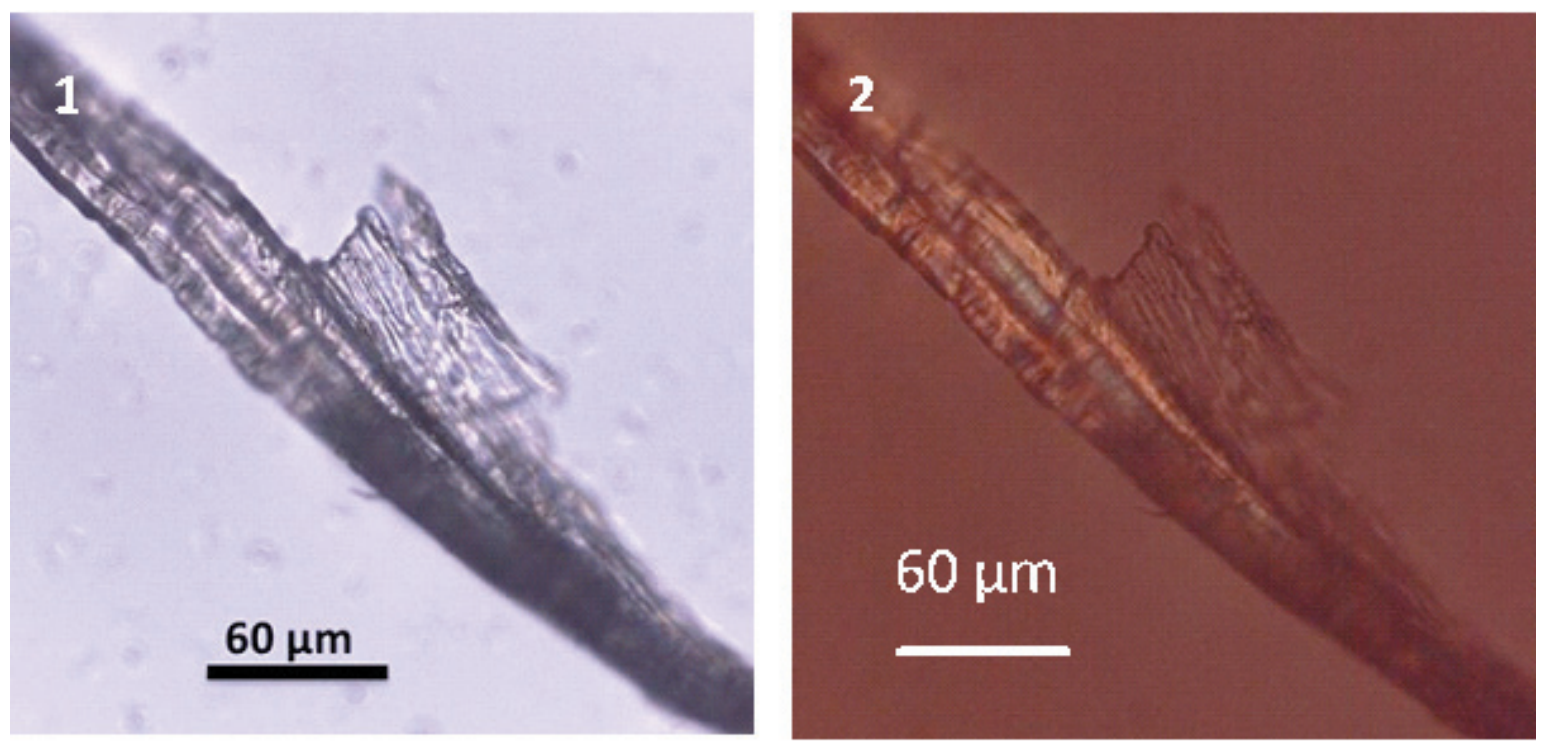

Imagen 13

Microscopio de transparencia. Fibra del sudario de León vista en aire con luz normal (izquierda) y con luz polarizada (derecha). Se está desprendiendo una placa de biocostra con posibles hifas de hongos, que deja al descubierto una fibra muy corroída. Los colores de polarización de bajo orden indican que la fibra está degradada y aplastada.
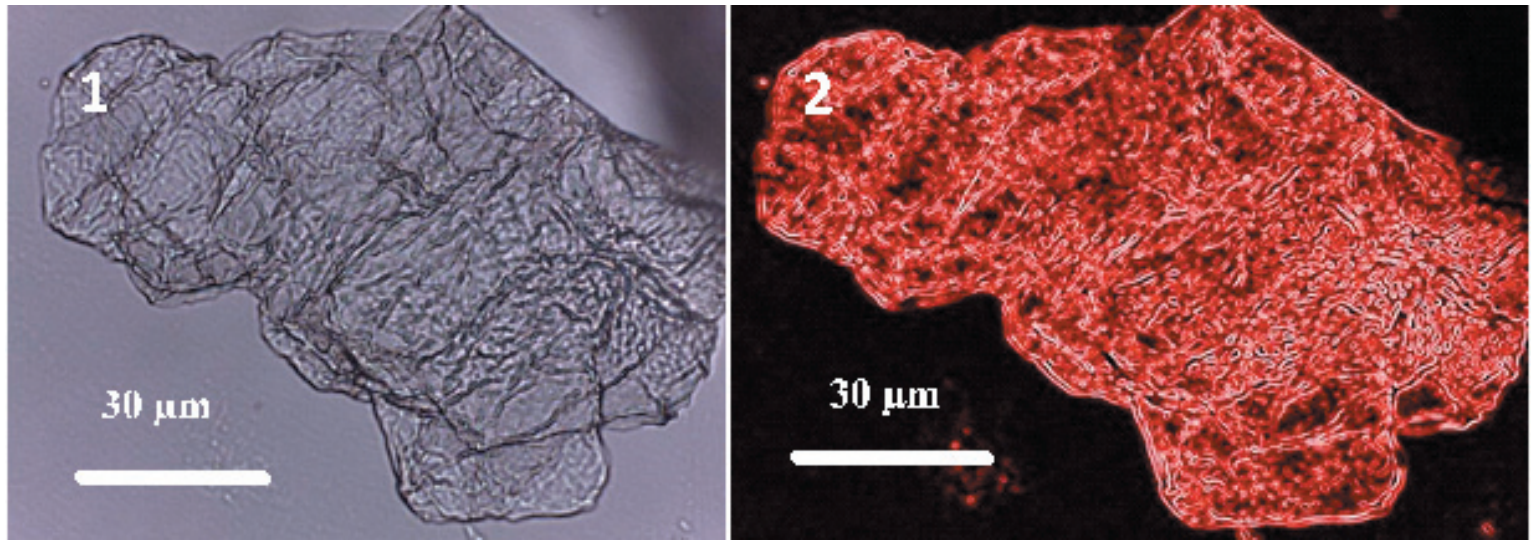

Imagen 14

Fotografía 1: Placa de biocostra desprendida, con abundantes adherencias e incrustaciones de posible microorganismos, vista con microscopio óptico de transparencia, en aire. Fotografía 2: La misma imagen tratada con el programa Picasa 3, que hace más evidente las formas compatibles con posibles microorganismos existentes. 

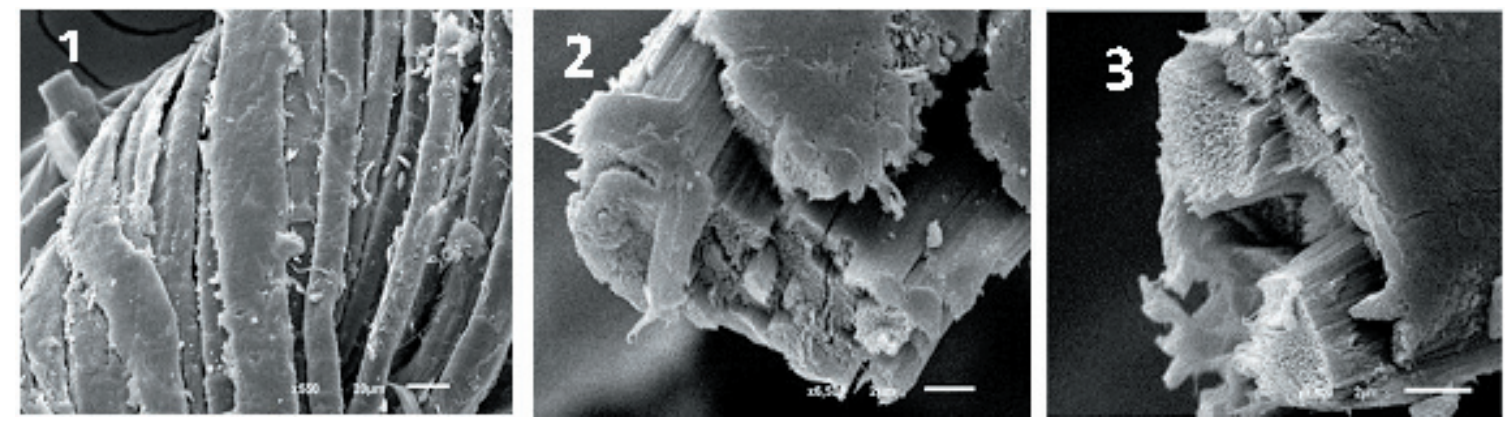

Imagen 15

Fotografía con MEB. Fotografía 1: Hilo del sudario de León, con biocostra recubriendo las fibras, más desarrollada cuanto más exteriores son las fibras. Fotografías 2 y 3: Vistas de dos fracturas de tensión recientes en dos fibras del sudario de León que presentan costra de biodegradación superficial y, a la vez, un interior muy sano, sin lumen ni biodegradación interna; lo que justificaría la elevada resistencia a romper de las fibras.
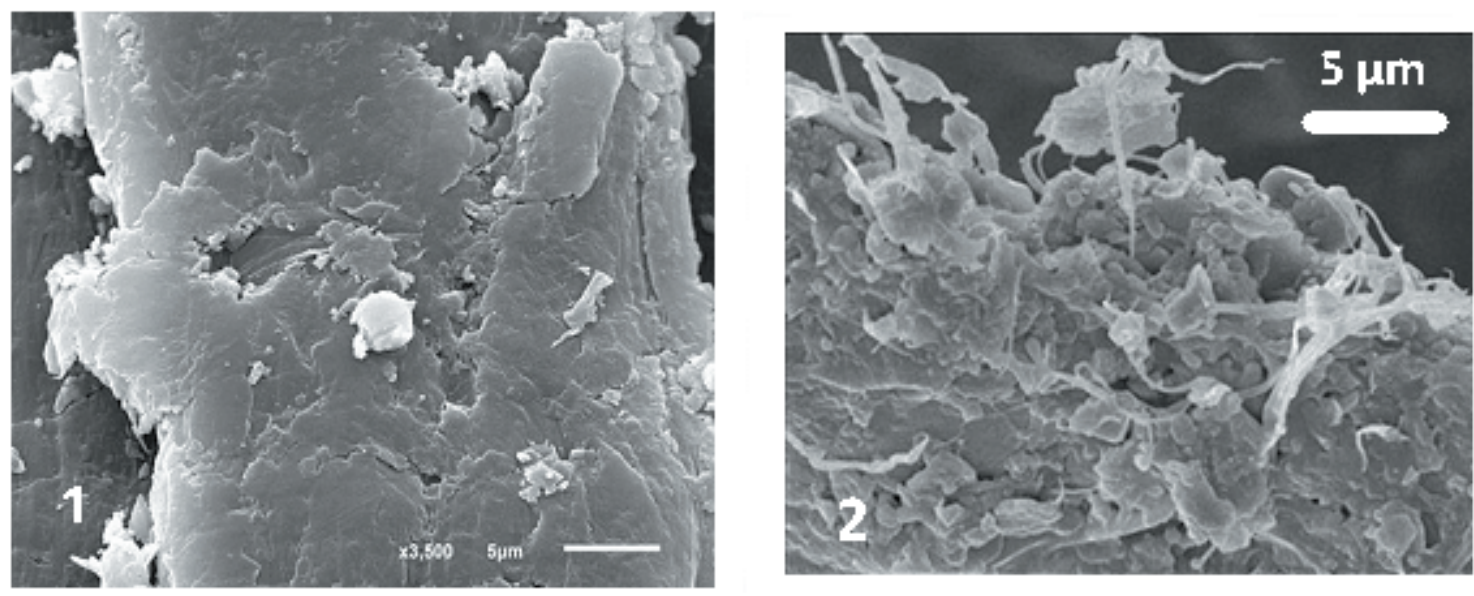

Imagen 16

Imágenes de MEB. Fotografía 1: Vista de fibra de lino del sudario de León, con recubrimiento típico de biocostra, análogo al que encontramos habitualmente en otras fibras de tela antiguas.

Fotografía 2: Vista de fragmento de biocostra, con su textura granulada, que justificaría la difusión de luz que observamos con el microscopio de luz transmitida.

La textura granulada que poseen las biocostras (imagen 16) justifica la difusión de la luz incidente y la disminución de la transparencia aparente de las fibras que recubre, cuando trabajamos con el microscopio de luz transmitida y con las fibras en aire. Y esa constatación de difusión de luz sería ya un indicio de biodegradación. También se constata que la difusión se elimina cuando introducimos las fibras en aceite de inmersión (ver imagen 17).

El color marrón que muestra el sudario podría llevarnos a pensar que la tela hubiese sufrido una impregnación con resina, pero no es así. El oscurecimiento de un tejido de lino inicialmente blanco es consecuencia normal de su envejecimiento, que implica, lógicamente, varios agentes (degradación mecánica, fotodegradación, biodegradación, etc.). 

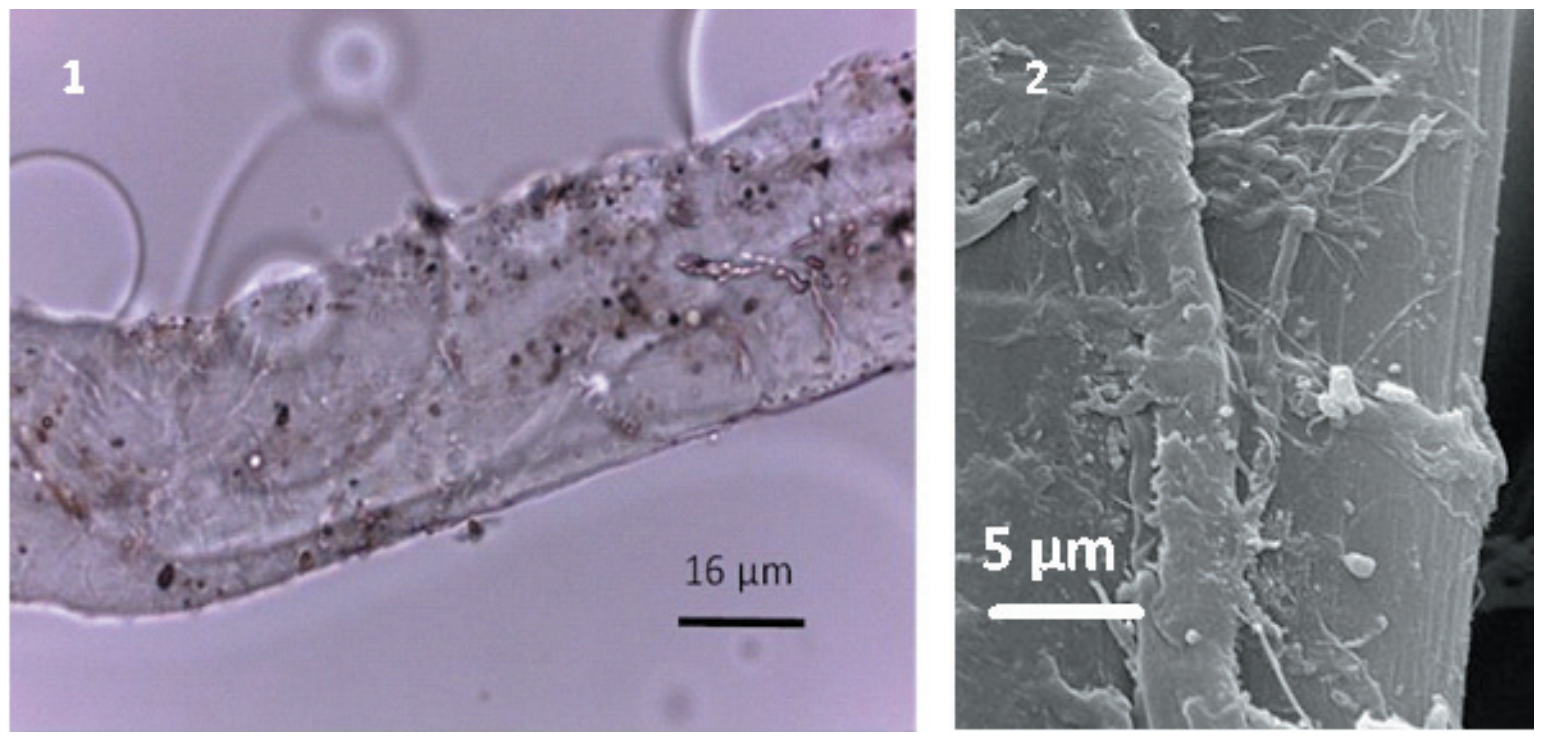

Imagen 17

Fotografía 1: Fibra de lino del sudario de León inmersa en aceite, vista con microscopio de transmisión y luz normal; muestra adherencias superficiales morfológicamente compatibles con microorganismos (hifas, esporas y bacterias). Se ve más transparente que las fibras en aire porque el aceite impide la difusión de la luz. Fotografía 2: Vista con MEB de la superficie de otra fibra de lino, en la que resultan más patentes los microorganismos adheridos, en especial posibles hifas de hongos.

En la superficie degradada de las fibras de nuestro sudario y en las biocostras asociadas, son normales y frecuentes las adherencias de partículas con formas compatibles con microorganismos. Se trata de un hecho esperado, conforme con los datos obtenidos en otros estudios sobre tejidos de lino antiguos, y también sobre el Sudario custodiado en la Catedral de Oviedo (Monte López, 1994).

La biodegradación observada en el sudario de León no es homogénea, algo usual en telas de lino antiguas. En concreto, en los flecos -donde las fibras de lino están más sueltas y sufrieron mayor degradación mecánica y biológica- encontramos mayor desarrollo de biocostras superficiales que en los hilos del tejido. También se observa que, en los hilos que tienen sus fibras torsionadas y apretadas, las fibras exteriores del hilo presentan más desarrollo de costra de degradación que las fibras interiores.

También se aprecia que existe una correlación clara entre los agujeros causados por biodeterioro y las líneas de pliegues del lienzo (ver imagen 18); aunque también encontramos algunos agujeros de biodegradación sin relación con líneas de plegado. Esa correlación se debe a que en las zonas de pliegue del sudario es donde las fibras de lino están más expuestas a rozamiento y donde sufren mayor deterioro mecánico y mayor desestructuración; lo que facilita la digestión de la celulosa por los microorganismos.

52 Estos aspectos parecen indicadores lógicos de que la biodegradación tiende a desarrollarse más sobre las fibras más expuestas al aire, y también sobre las que presentan mayor deterioro mecánico. 


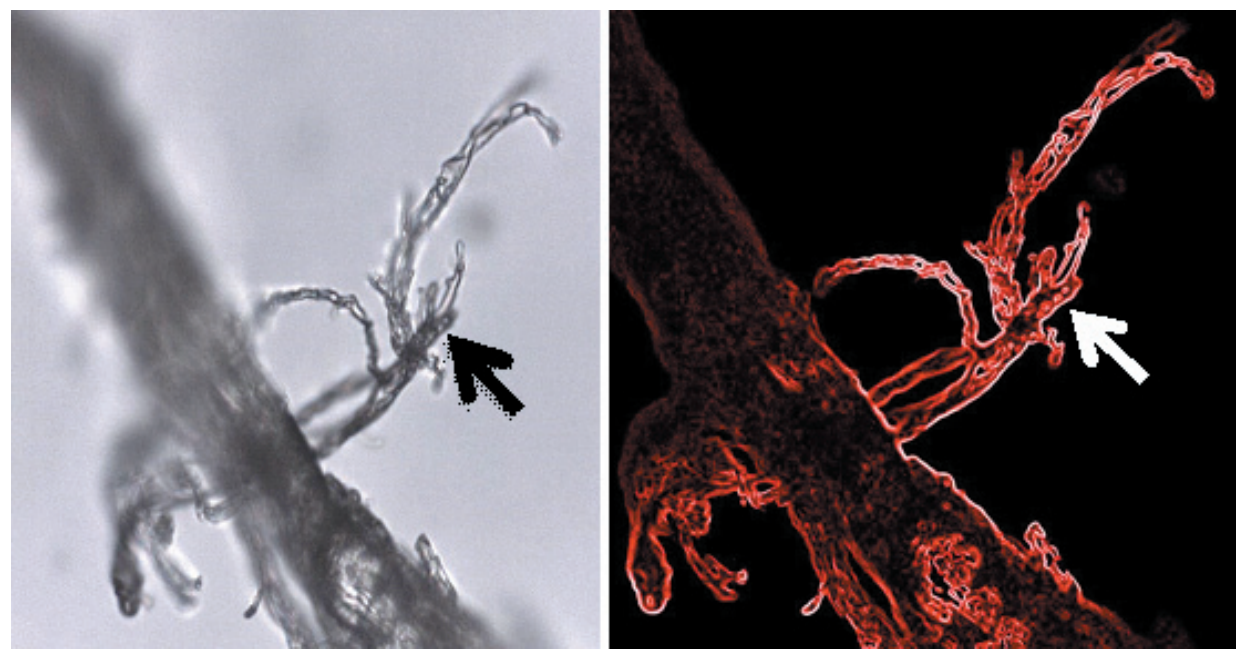

Imagen 18

Microscopio de transparencia, luz normal. Fotografía 1: Posibles hifas de hongos con esporas incluidas, implantadas sobre fibra de lino del sudario de León.

Fotografía 2: Imagen obtenida procesando la anterior con el programa Picasa 3, que hace más evidentes hifas y esporas (se señala un punto donde esas esporas aparecen más diferenciadas).

La formación de huecos por biodegradación del lienzo resulta más evidente cuando dichos huecos aparecen ligados a manchas de líquidos orgánicos, tal como vemos en la imagen 19. El material orgánico causante de esas manchas posiblemente tenía contenido hemático, que facilitó la implantación y desarrollo de los microorganismos, quienes terminaron comiéndose la celulosa de las fibras de lino que servían de soporte. Este mismo fenómeno lo observamos en el Sudario de Oviedo, donde encontramos huecos de biodegradación desarrollados en puntos del tejido en los que existen restos de coágulos de sangre.
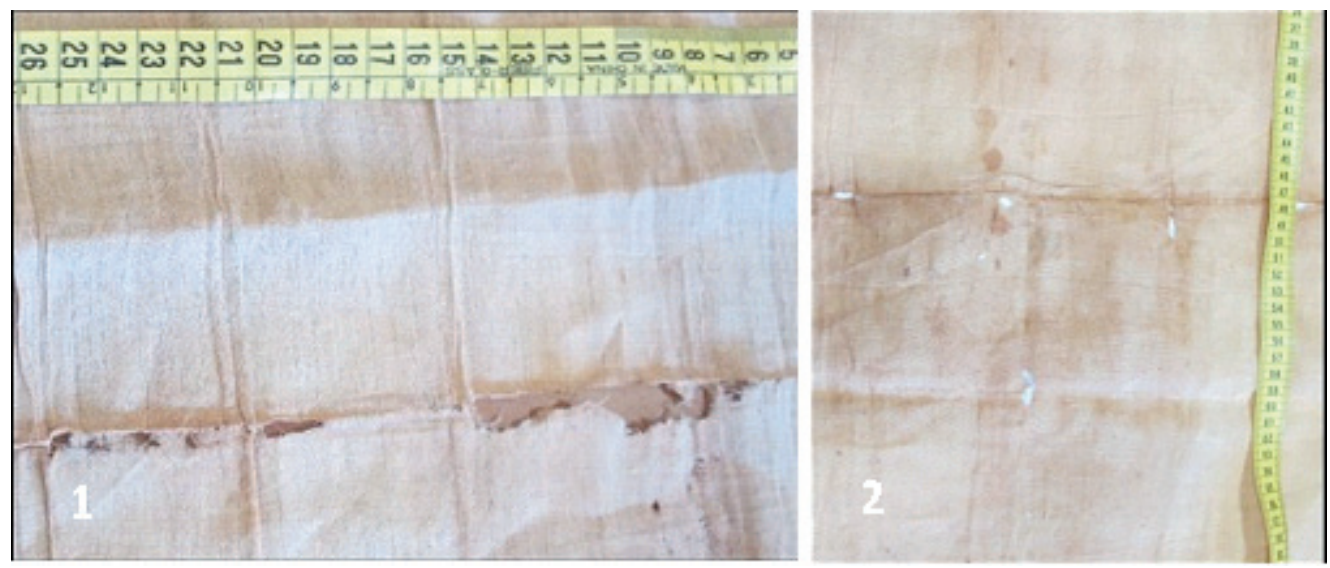

Imagen $19 a$

Fotografía 1: Los agujeros debidos al deterioro del tejido se localizan sobre líneas de pliegue que corresponde al sistema perpendicular al eje mayor del sudario; es en esas zonas donde las fibras sufrieron un mayor deterioro mecánico y donde resulta lógico encontrar una intensificación de la biodegradación. Fotografía 2: Otros huecos de biodegradación también ligados a líneas de pliegues con manchas redondeadas causadas por goteo estando el lienzo plegado. 


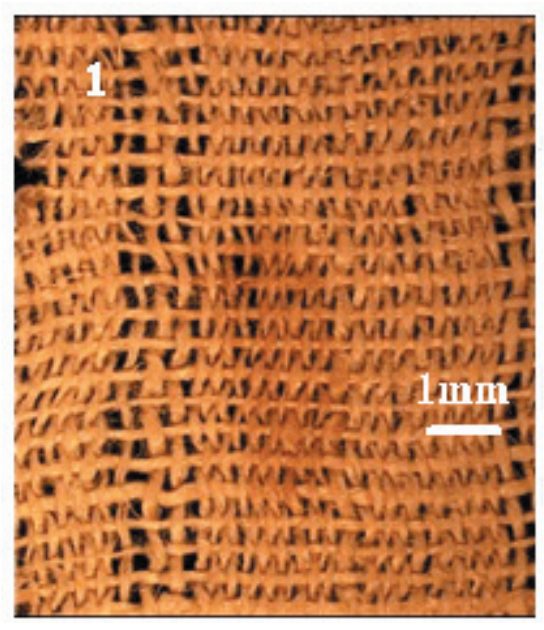

\section{Imagen $19 b$}

Manchas formadas por goteo de líquido con posible contenido hemático. Fotografía 1: Zona del tejido que presenta bandas diferenciadas por un desigual apretado de hilos de trama, con mancha de forma elipsoidal, que indica cierta inclinación del tejido. Fotografía 2: Mancha con coloración más oscura (posible mayor carga hemática), y con biodegradación centrada en ella.

En el estudio con microscopio de transparencia hemos observado, usando objetivos de fuertes aumentos, la presencia de películas de líquidos viscosos sobre la superficie de algunas fibras, tanto de lino como de algodón contaminante (imagen 20). Estos líquidos pueden ser biofilms activos. Dato que subraya aún más la conveniencia de revisar y mejorar las condiciones de conservación del sudario.
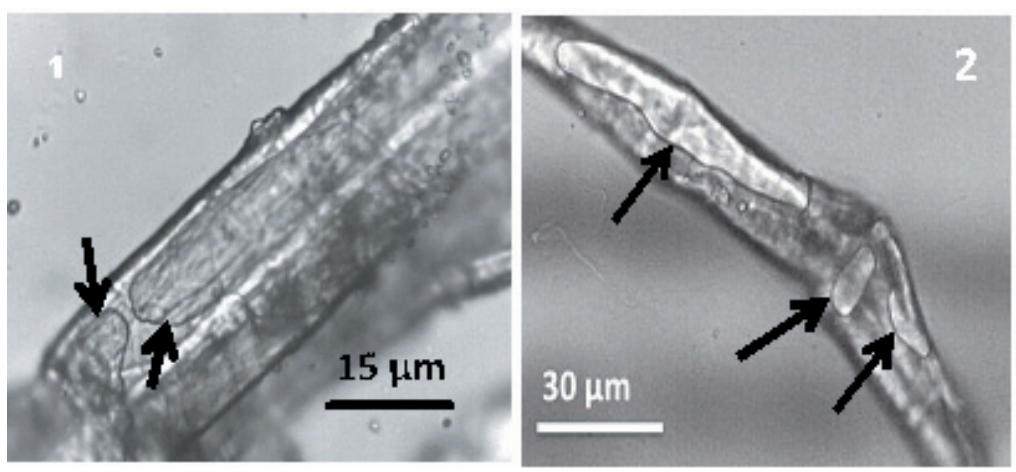

Imagen 20

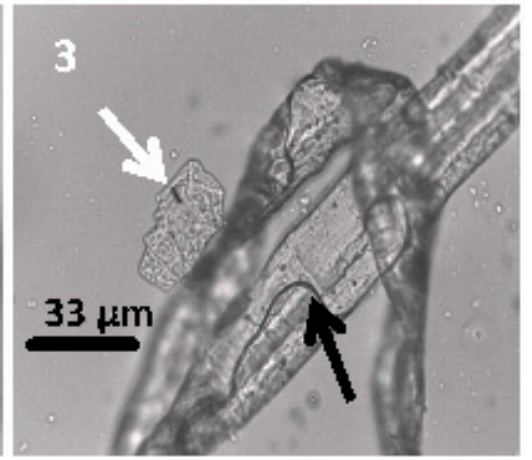

Posibles biofilms, constituidos por películas de un líquido viscoso ligado a la superficie de fibras de lino (fotografías 1 y 2), y de algodón y lino (fotografía 3). Las películas se señalan con flechas negras. Los biofilms indicarían una biodegradación actual del sudario.

La flecha blanca de la fotografía 3 señala un fragmento de placa de biocostra.

No cabe duda de que sobre el sudario de León se ha desarrollado, tanto sobre fibras individuales como sobre hilos, un proceso de biodegradación, del que las biocostras derivan. Dicho proceso afecta fundamentalmente al exterior de las fibras de lino, mientras que observamos un interior sano y compacto (ver imagen 15): No hemos observado en los estudios microscópicos, incluyendo los hechos con el MEB, 
ni lumen ni huecos interiores causados por biodegradación interna. Este hecho puede justificar la flexibilidad de las fibras, así como su elevada resistencia a la rotura.

Las biocostras del sudario de León aquí estudiadas resultan similares a las encontradas en otras telas de lino antiguas, constituidas por una sustancia con propiedades típicas: blanda, incolora e isótropa (no polariza en el microscopio de transparencia); posee textura microgranulada, es frágil y se desprende con facilidad de hilos y fibras al manipular las muestras de tejido, dando fragmentos de tamaño muy variado, que suelen contener adherencias e incrustaciones de microorganismos. Esta biocostra actúa como difusora de la luz incidente, enmascarando la transparencia de las fibras. $Y$, aunque resulta perfectamente identificable con el microscopio óptico de transparencia, la mejor manera de caracterizarlas es utilizando un MEB.

Por la simple comparación de las características de biodegradacion que afectan a as fibras de lino del sudario de León y a las de fibras de lino del Sudario de la Catedral de Oviedo, cabe concluir que existen coincidencias notorias entre las dos telas en cuanto al grado de desarrollo y las características de la biodegradación que presentan; así como en cuanto a las propiedades mecánicas de sus hilos y fibras (flexibilidad y resistencia a la rotura). Sin olvidar que, en teoría, a los dos tejidos se les atribuye una misma edad (siglo I) y un mismo origen (Palestina).

\subsection{Los secretos del dobladillo}

El dobladillo que remata los bordes izquierdo y derecho del sudario de León, tal como se indicó, nos impedía ver si en ellos el tejido presentaba o no orillo (ver imagen 6). Por lo que, utilizando una muestra extraída de la esquina inferior del borde izquierdo que incluía dobladillo, procedimos a deshacerlo para exponer el borde de la tela, buscando respuesta.

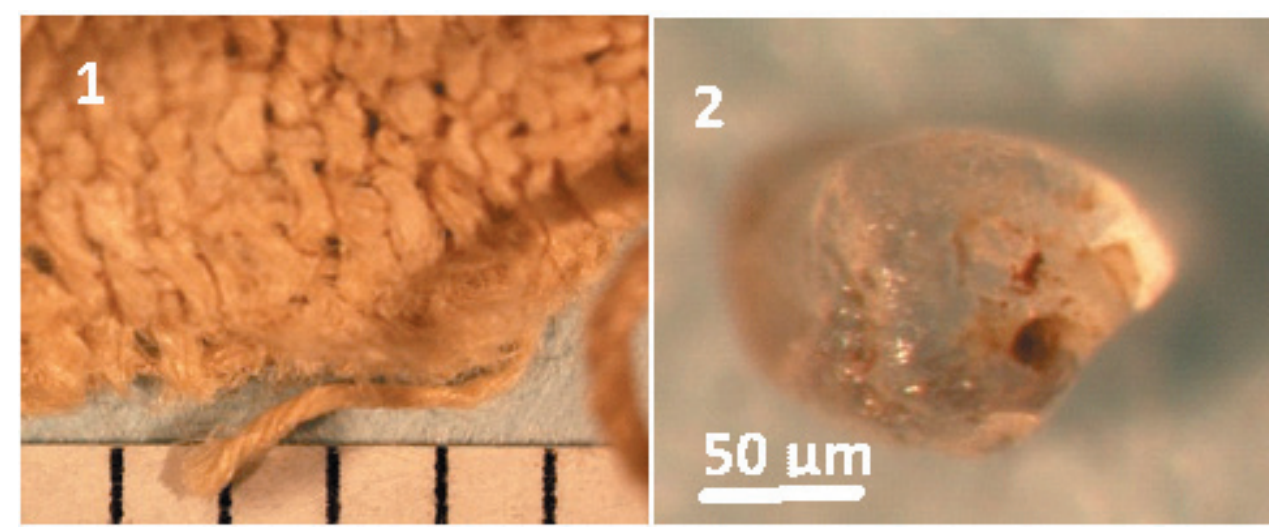

Imagen 21

Fotografía 1: Al deshacer el dobladillo encontramos un borde sin orillo, formado por corte del tejido. Fotografía 2: Grano de cuarzo con elevado grado de redondez y superficie esmerilada (indicadores de erosión eólica), encontrado en el interior del dobladillo. 
La carencia de dobladillo en el borde superior, que presenta terminación con orillo, nos lleva a sospechar que los bordes con dobladillo eran bordes carentes de orillo, motivo por el que precisarían ese remate para evitar el deshilachado del tejido.

Lo encontrado confirmó la sospecha: Se trataba de un borde carente de orillo y que muestra terminación por corte (imagen 21.1). Lógicamente, suponemos que en el borde opuesto el dobladillo corresponda a una circunstancia análoga. Consecuentemente, podemos concluir que los orillos fueron realizados no como un detalle de mejora estética del sudario, sino como un remate necesario para evitar el deshilachado del tejido. Necesario si lo que se pretendía era confeccionar una prenda de uso personal; innecesario y absurdo (por el coste que implicaría), si se tratase de un tejido destinado desde el principio a simples fines funerarios.

Otro dato interesante revelado por el dobladillo fue descubrir en su interior algunos granos de cuarzo con características propias de arena de ámbito desértico (imagen 21.2). Ese sería, sin duda, el ámbito geográfico del taller en el que se confeccionó el sudario de León, pues esos granos de cuarzo eólico habrían sido incorporados en el momento y en el lugar en que se cosió el dobladillo.

\subsection{Fibras contaminantes}

Se han encontrado fibras contaminantes algunas de ellas teñidas, de algodón, lino y lana (ver imágenes 22 y 23). Entre las de algodón, se ha observado tanto fibras sin teñir como teñidas en rojo, en azul y en marrón (imagen 22). Se han identificado también alguna fibra de lino azul y de lana roja. Asimismo se ha observado la presencia de algún cabello ligado a la superficie del sudario, cuya incorporación podría ser incluso reciente.
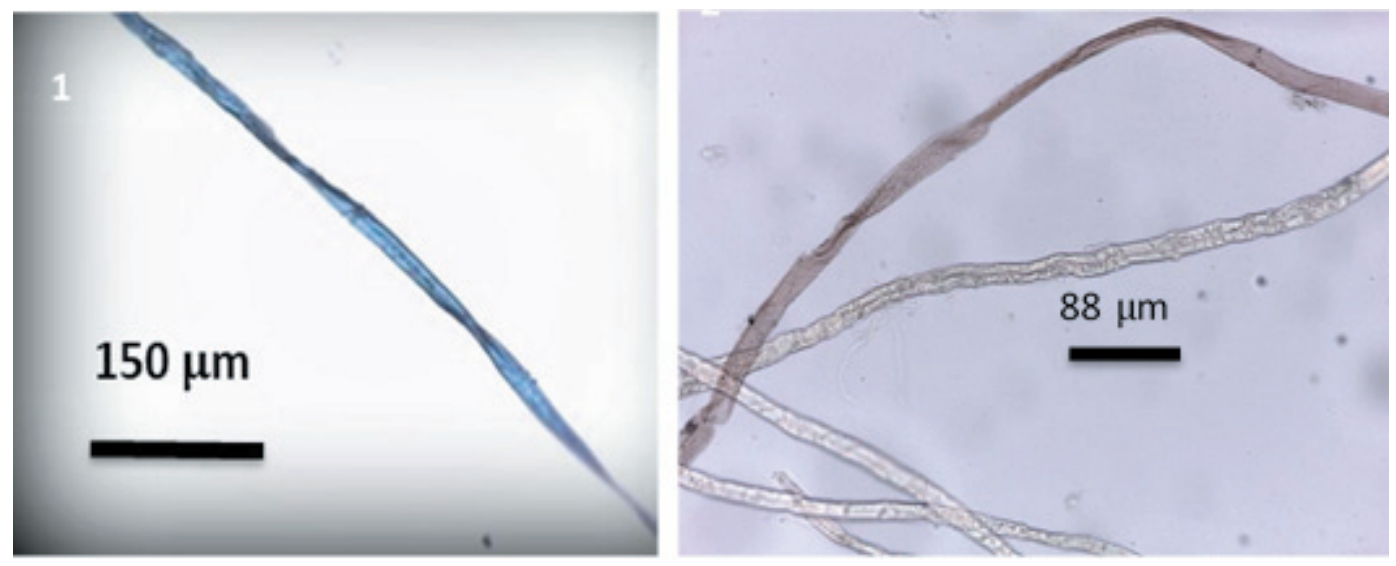

Imagen 22

Fibras en aceite, vistas con microscopio de transparencia y luz normal.

Fotografía 1: Fibra de algodón azul. Fotografía 2: Fibra de algodón marrón (la más oscura) acompañada de otras de lino. Las dos provienen de hilos del sudario, y podrían representar contaminaciones durante el hilado. 

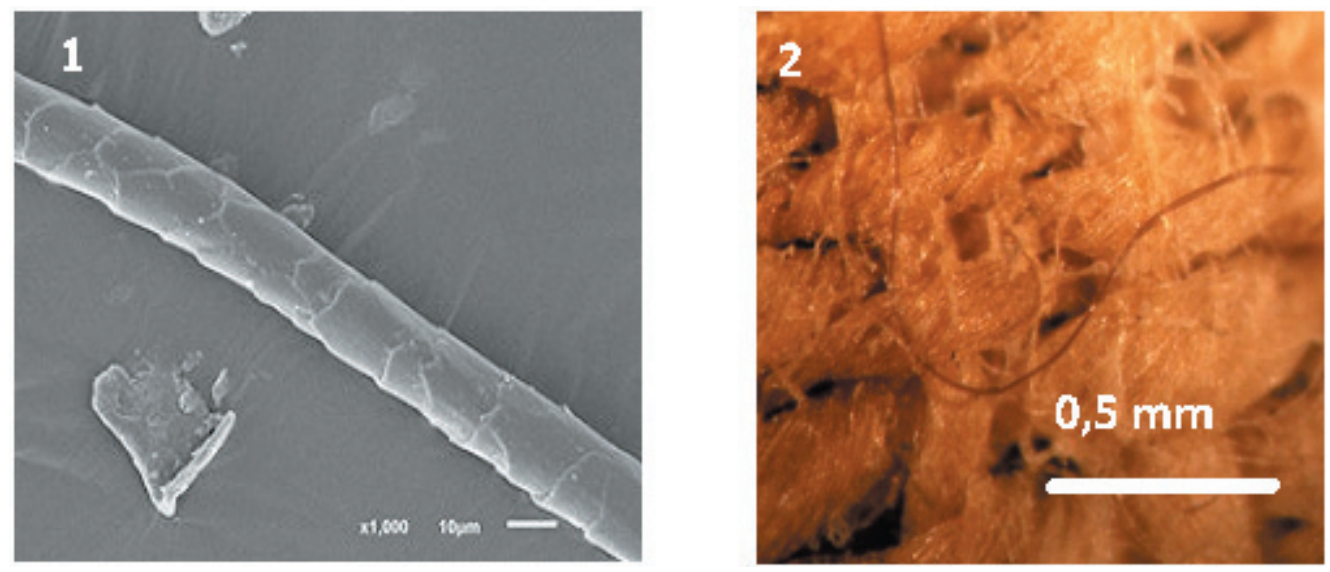

Imagen 23

Fotografía 1: Fibra de lana vista con MEB, en la que se aprecia la buena conservación de su superficie, sin microorganismos y sin erosión mecánica. Fotografía 2: Posible cabello humano ligado al tejido, en una zona donde los hilos muestran una fuerte impregnación que ha causado ligazón de las fibras de lino.

La presencia de estas fibras textiles resulta algo aleatorio y accidental, y no es mucha la información que aportan. En el caso de las fibras de algodón, podemos constatar, por su grado de biodeterioro, que se trata normalmente de fibras contaminantes antiguas. Algunas que estaban integradas en hilos del sudario, nos indicarían que fueron incorporadas en la fase de hilado; las que se encuentran suelas podrían ser fibras contaminantes desprendidas de prendas de uso personal. En cualquier caso, son prueba de que, en aquel momento y en aquel taller, el lino y el algodón convivían.

Así como las fibras de lino y de algodón se ven muy degradadas, la lana, en cambio, muestra una superficie poco degradada; lo que podría corresponder a una contaminación reciente.

\subsection{Gotas de cera}

Se ha observado la presencia de varias gotas de cera adheridas al sudario de León (ver imágenes 24 y 25). Es una sustancia fácilmente identificable, por sus propiedades físicas: incolora, típico brillo céreo, baja dureza al rayado; tienen morfología de gotas de un líquido viscoso y de rápida solidificación por enfriamiento; y, además, encontramos que incluye abundantes partículas de la característica carbonilla que se forma durante la combustión y quema de las mechas de velas de alumbrado.

Por la morfología que presentan dichas gotas, se deduce que cayeron verticalmente impactando sobre la superficie expuestas del sudario, estando esta plana pero afectada de cierta inclinación. También se deduce que la altura de las velas sobre el tejido en el que impactaron las gotas de cera sería escasa, ya que estas no llevaban la fuerza suficiente para romper en el impacto y formar grupos de gotas de menor tamaño, ni siquiera mínimas salpicaduras en el entorno inmediato, tal como se refleja en las imágenes 24 y 25. 

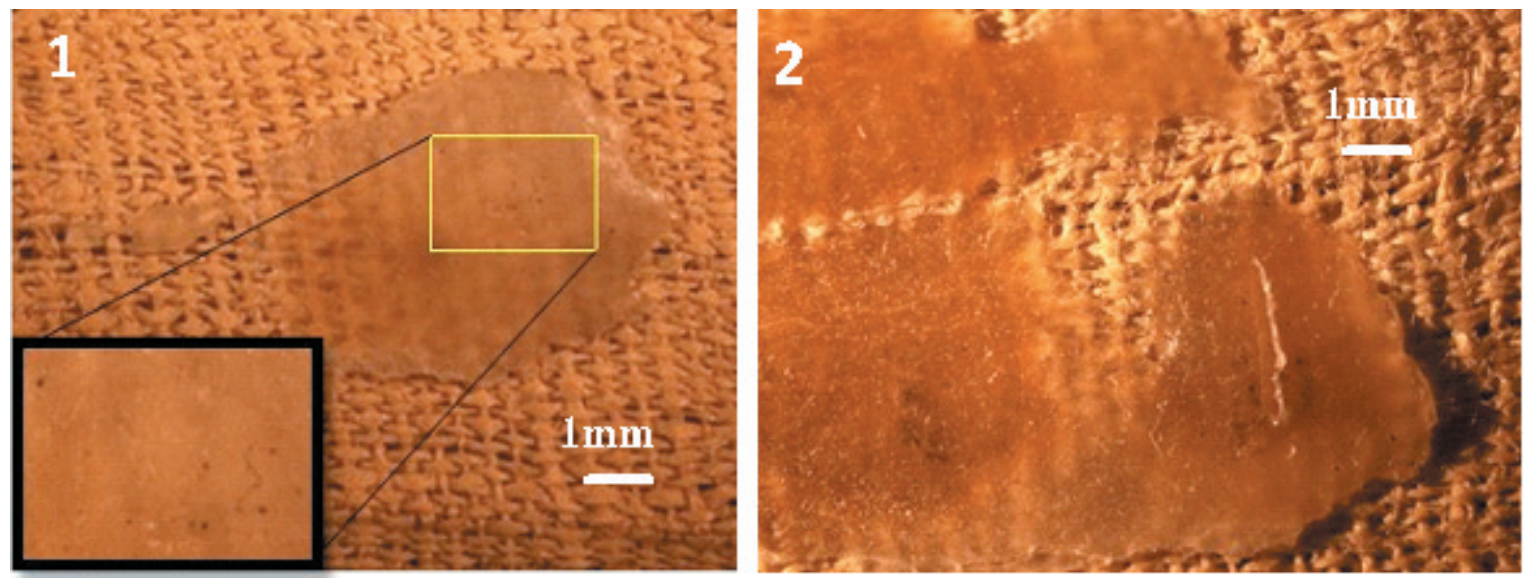

Imagen 24

Gotas de cera de vela que incluyen partículas de carbonilla. En la fotografía 2 se muestra la baja dureza al rayado de la cera. La morfología de las gotas de cera indica que cayeron verticalmente sobre el tejido, estando este ligeramente inclinado de izquierda a derecha.
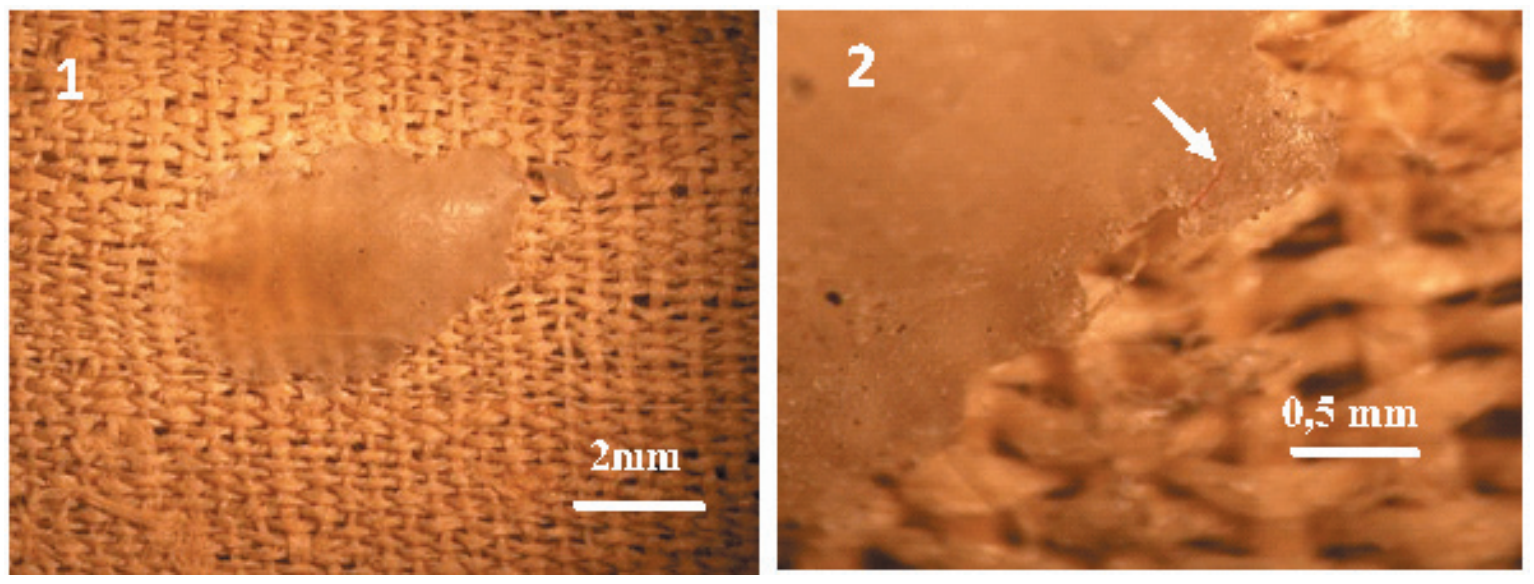

Imagen 25

Fotografía 1: Gota de cera cuya forma muestra fluencia con dirección SW-NE, por inclinación del tejido. Fotografía 2: Ampliación del borde de la gota anterior, mostrando partículas de carbonilla incluidas; y también una fibra roja (se señala con flecha), que nos demuestra que ella estaba ya allí cuando la cera cayó sobre el sudario y la englobó.

Otro dato interesante es el hallazgo de alguna fibra de color rojo incluida en la cera (imágenes 24 y 25). Nos indica que esa fibra ya estaba contaminando el tejido en el momento en que la gota de cera cayó sobre el sudario, y sería prueba evidente de una antigüedad no menor a la de la misma cera.

Se deduce, pues, que esa cera es una contaminación debía a simples gotas caídas de velas de alumbrado, usadas por personas que estuvieron en el lugar donde el sudario estaba depositado, posiblemente una cavidad subterránea privada de iluminación natural. 


\subsection{Manchas de cal}

Otra contaminación significativa de la tela la constituyen placas de lechada de cal caída sobre ella en forma de gotas (ver imágenes 26 a 28). Aunque algunas de esas placas se conserva completa (imagen 26), la mayoría fueron erosionadas, quedando únicamente restos que rellenan los huecos entre hilos, y que resultan protegidos por estos. Por la forma tan redondeada que muestran estas placas y por su aplastamiento, puede afirmarse que son debidas a gotas que caen verticalmente sobre una tela dispuesta en posición horizontal. Además, son varias las razonas que nos indican que se trata de una lechada de cal densa (poco fluida): no generó salpicaduras que se proyecten en su entorno; penetró y rellenó los espacios entre hilos, pero sin apenas percolar al otro lado; formó bordes muy definidos y netos, sin irregularidades debidas a filtración lateral en el lienzo por capilaridad o difusión.

La cal se incorporó al sudario antes de ocurrir la contaminación con los fluidos con posible carga hemática, ya señalados. Eso nos lo muestra alguna de esas manchas de cal bien conservada, como la que tenemos en la imagen 26, sobre la cual se observa el impacto de una gota de fluido con posible carga hemática.

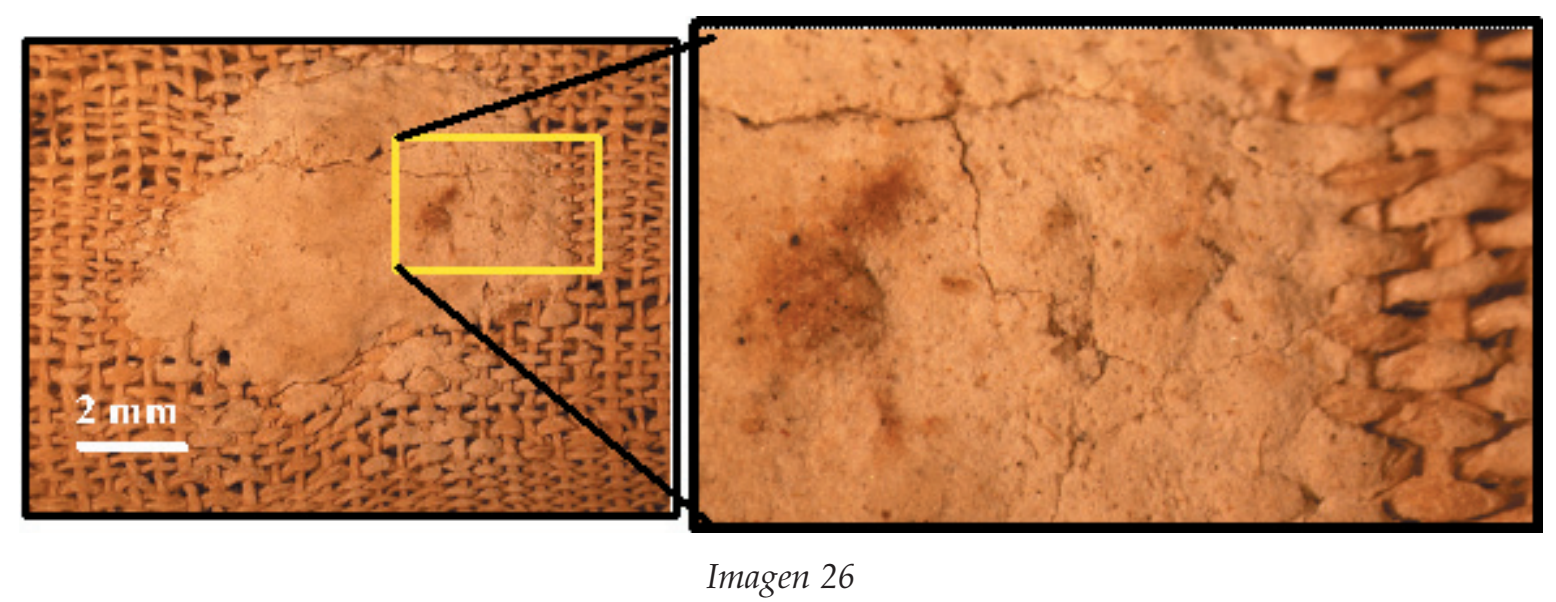

Placa de cal con textura microgranulada. Se formó a partir de una gota de lechada que cayó estando el tejido horizontal. La lechada era poco fluida, pues rellenó y colmató huecos entre hilos, pero sin percolar, formando una placa plana y casi circular. Presenta una mancha rojiza por impacto de una gota de fluido con posible carga hemática.

En estas manchas compuestas originalmente por cal, actualmente encontramos un agregado de aspecto sacaroide constituido por granos mono y policristalinos de calcita idiomórfica, claramente autígena: Esta calcita se formó sobre el propio tejido por reemplazamiento de la cal (ver imagen 28). Estos granos de calcita se desagregan y sueltan con facilidad; lo que facilita su dispersión sobre el propio sudario, o incluso su integración en el polvo local.

El idiomorfismo de la calcita, especialmente apreciable en las fotografías con MEB de la imagen 28, nos indica que no sufrieron transporte ni redondeamiento; por lo que no es posible considerarlos como polvo eólico exterior llegado en sus- 
pensión. Siempre nos indicarán transporte cero y fuente inmediata, aunque apareciesen mezclados con otros componentes de origen claramente eólico (granos minerales con fuerte redondeamiento, cenizas volantes, esporas, etc.).

La identificación de esta calcita resulta fácil con el microscopio de transparencia; también por la característica reacción que da al establecer contacto con una gota de solución diluida de $\mathrm{HCl}(10 \%)$ (ver imagen 27). Además, por medio del analizador EDX del MEB, también se verificó que se trataba de cristales de carbonato cálcico.
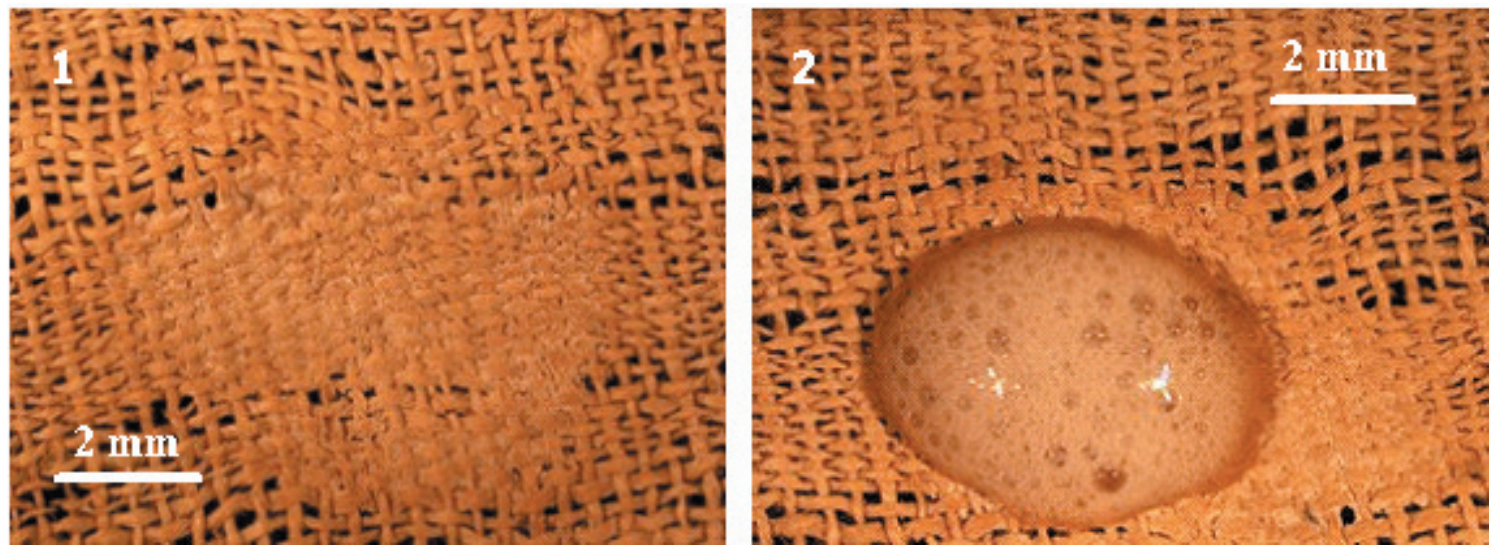

Imagen 27

Restos de manchas de cal erosionadas; la cal ha sido reemplazada por cristales de calcita de neoformación. En la fotografía 2 vemos la característica reacción de la calcita con una gota de solución diluida de $\mathrm{HCl}(10 \%)$.

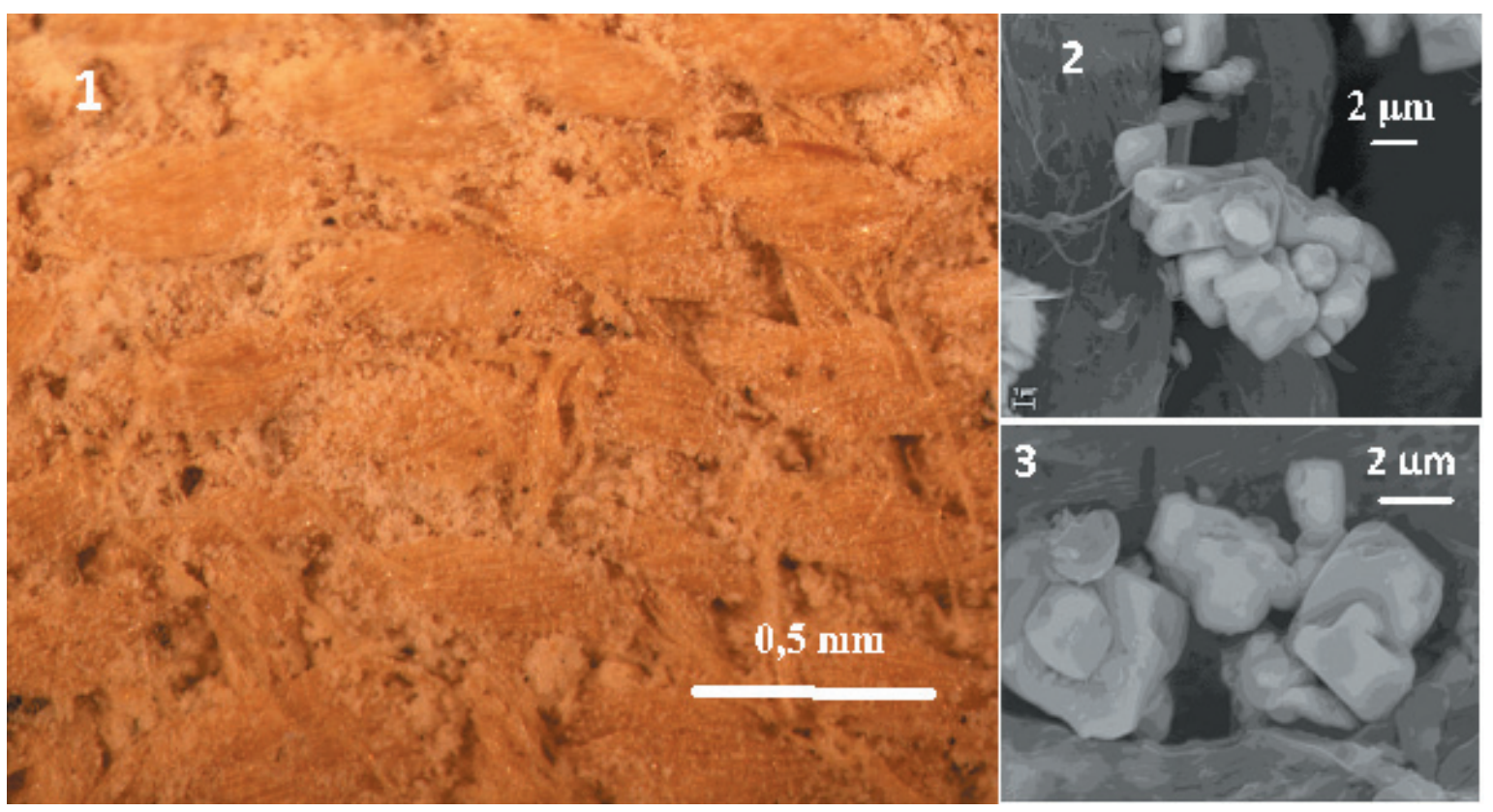

Imagen 28

Fotografía 1: Aspecto sacaroide del relleno que dejó una placa de cal desprendida. Está constituido por microcristales de calcita idiomorfa, que reemplazó a la cal. Fotografías 2 y 3: Vistas con MEB de granos policristalinos de la calcita anterior, que muestran claramente su idiomorfismo. 
Dentro de los restos de cal, encontramos también inclusiones de cuarzo eólico (elevado índice de esfericidad y superficie esmerilada), característico de ámbitos desérticos (imagen 29). Su presencia como parte integrante de la lechada de cal original delata simplemente que esta se habría fabricado y utilizado en un área desértica.
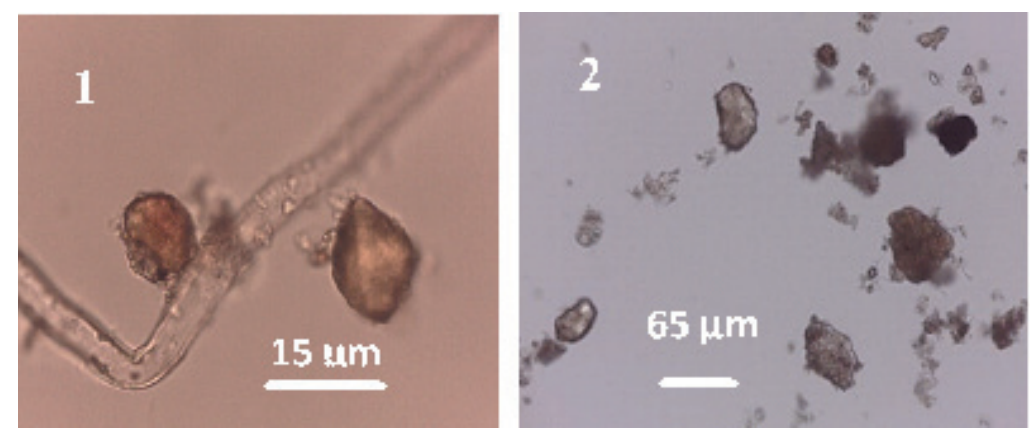

Imagen 29

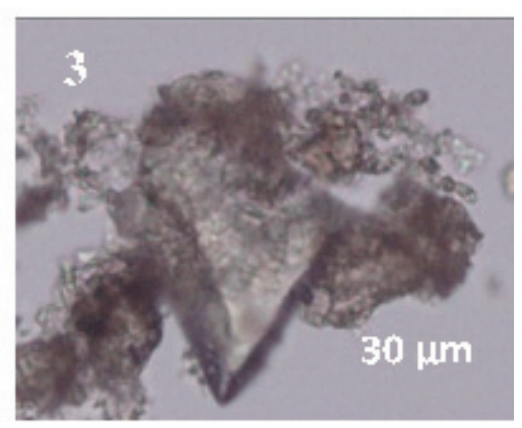

Granos de cuarzo incluidos en la placa de cal. Fotografías 1 y 2: Granos de cuarzo con elevado índice de redondez y superficie "esmerilada", indicadores de erosión eólica (son granos de polvo de ámbito desértico que contaminaron la cal).

Fotografía 3: Esquirlas de cuarzo de fragmentación mecánica; no sufrieron transporte ni redondeamiento, y formarían parte del polvo generado en la excavación de la cavidad subterránea donde estuvo el sudario, que es donde lo incorporaría la cal.

Además de los granos redondeados de cuarzo, la cal también contenía esquirlas angulosas de cuarzo, producidas por fragmentación mecánica y carentes de redondeamiento, lo que indica ausencia de transporte. Esquirlas con esta morfología son componentes típicos del polvo generado en la excavación de cualquier cavidad en una roca silícea tipo arenisca.

Mientras que el cuarzo eólico sirve para localizar la cal en un ámbito desértico, el cuarzo anguloso nos sitúa en el interior de un hueco excavado en roca silícea, dentro de la cual se encontraba el sudario en el momento de ser alcanzado por las gotas de cal.

\subsection{Restos de suelo}

En lo que parece un fragmento de suelo consolidado, que se presenta como una adherencia sobre la superficie del sudario de León (ver imagen 30), encontramos englobado un material detrítico muy heterogéneo. Entre los granos de cuarzo se distinguen bien algunos muy redondeados, con morfología derivada de erosión eólica. Son granos reveladores de que ese suelo pertenece a un área desértica. Pero, si tenemos en cuenta que ese material (el suelo), por su friabilidad y tamaño, no resiste el transporte eólico mínimo, necesariamente tiene que haber sido captado por el tejido en su área de procedencia y muy cerca de su fuente. 
Se puede también establecer que este fragmento de suelo, por tamaño y peso, no puede haberse incorporado al sudario como un grano en suspensión en el aire; por lo que se habrá incorporado por contacto directo del tejido con el suelo de alguno de los lugares en los que estuvo: un taller, o el mismo suelo del último lugar de residencia, ya que su modo de fijarse al tejido es muy precario, y no habría resistido mucho trasiego sin desprenderse. Además, se pone en evidencia que esa incorporación de la partícula de suelo al sudario se realizó al tiempo que actuaba una presión que forzó su inserción en el tejido, a la vez que deformaba los hilos en los que se incrustaba (ver imagen 30).

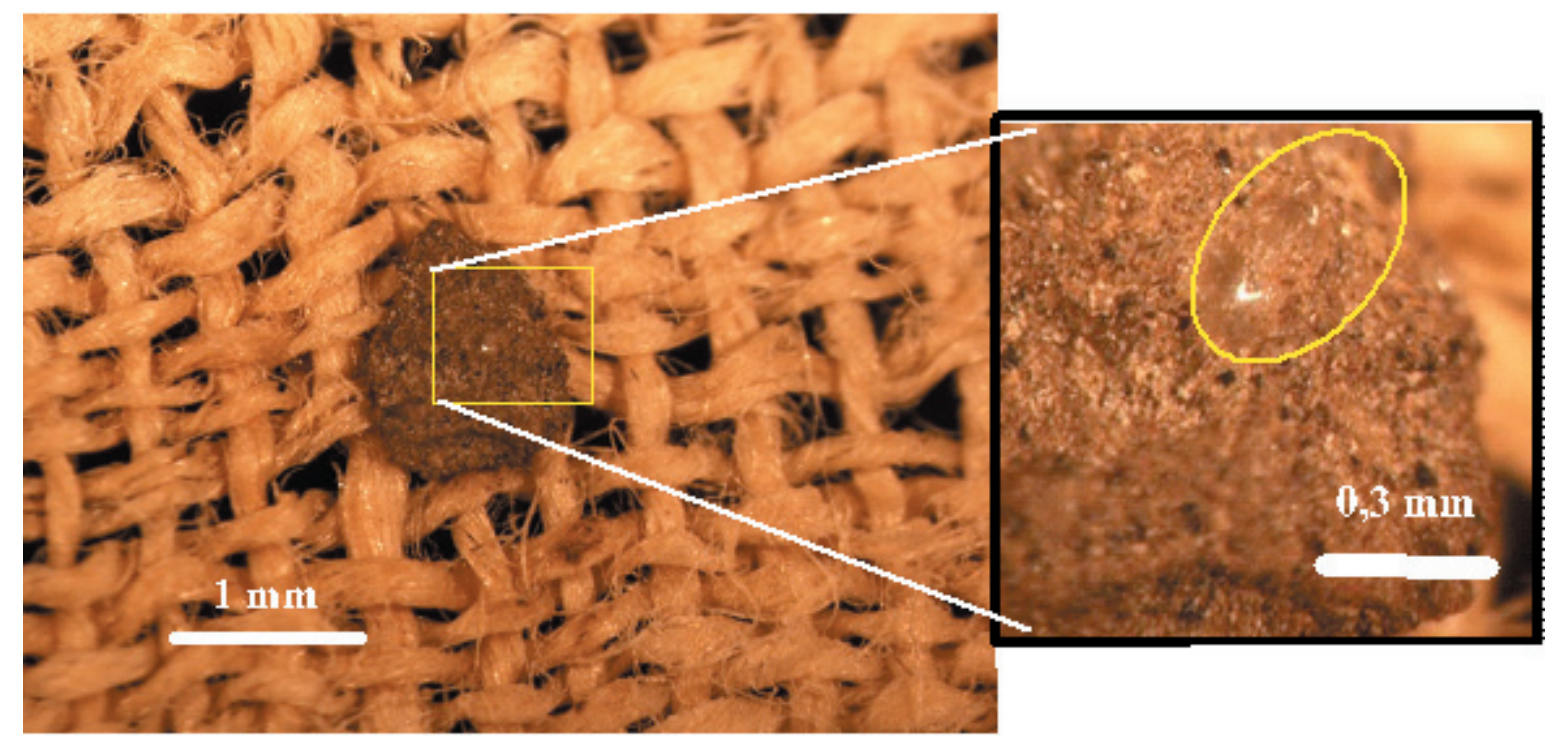

Imagen 30

Partícula de suelo, friable y no resistente al transporte. Incluye material detrítico heterogéneo, y no clasificado, con presencia de granos de cuarzo con superficie muy redondeada y pulida por desgaste eólico. La partícula se incrustó en el tejido por contacto bajo presión, forzando y deformando los hilos. A la derecha, con mayores aumentos, observamos el carácter muy redondeado de un grueso grano de cuarzo.

\subsection{Posibles fragmentos de láminas de papiro}

Ligadas al tejido, y más en concreto como material enredado entre las fibra de lino, se observa la presencia de fragmentos de posible papiro, que, por su forma plana y su textura parecen ser fragmentos de láminas obtenidas por corte longitudinal de un tallo (imagen 31). Algunas de menor tamaño ligadas a hilos que aún conservan torsión, podrían corresponder a contaminaciones en la misma fase de hilado; otras son adherencias posteriores, que se encuentran enredadas entre fibras de los flecos, o formando parte de un ovillo de fibras sueltas que permanece adherido al sudario. La conclusión que cabe sacar es que el sudario tuvo una evidente relación física con un taller en el que se trabajaba el papiro. Lo cual sigue siendo un claro indicador del ámbito de procedencia de nuestro sudario. 

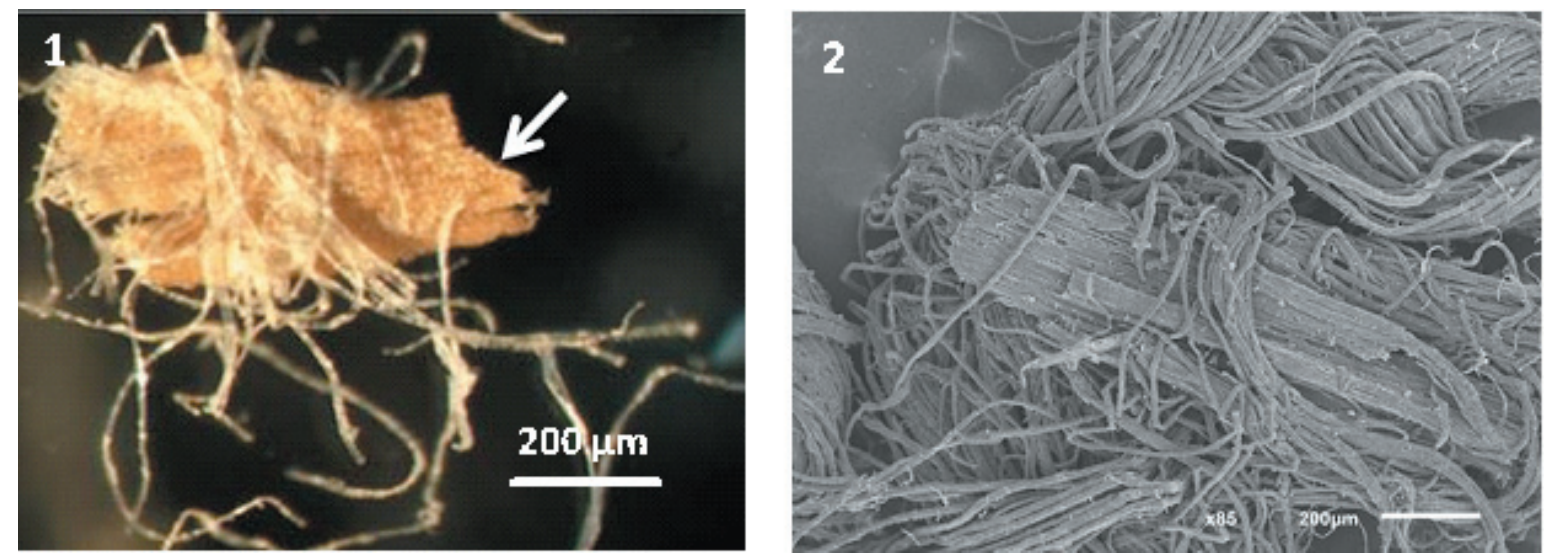

Imagen 31

Fotografía 1: Vista con microscopio óptico e iluminación episcópica de un fragmento de papiro enredado entre fibras de lino del sudario de León. Fotografía 2: Vista con MEB de otro fragmento laminar de papiro, integrada en un fleco del sudario, cuyas fibras aún conservan algo de torsión (podría ser una contaminación durante el hilado).

\subsection{Sobre el material biológico presente}

Como material biológico contaminante, lo más importante es sin duda, la abundantes presencia de biocostras y de estructuras compatibles con microorganismos colonizadores del tejido -bacterias, hifas de hongos, esporas- (ver imágenes 32 a 34), que podrían ser indicadores de una biodegradación que aún sigue activa.

Se han localizado estructuras compatibles con esporas, en las que el análisis atómico con EDS muestra que están constituidas exclusivamente por carbono y oxígeno, sin otros elementos, lo que nos demuestra su naturaleza orgánica.
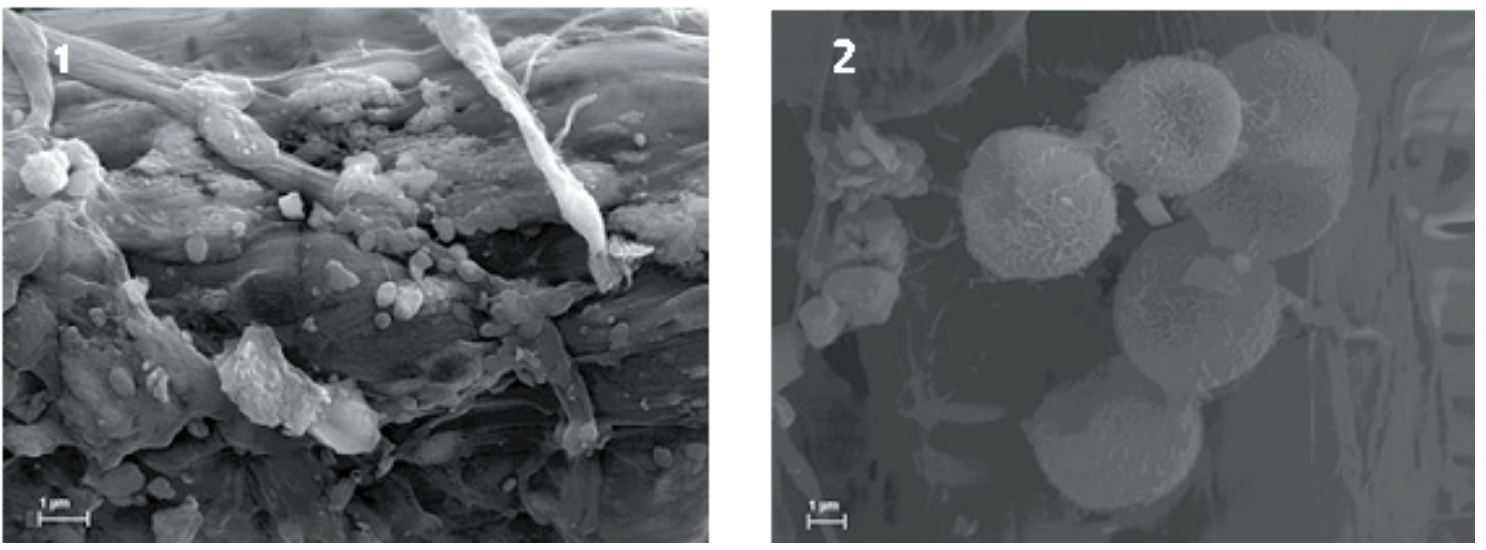

Imagen 32

Imágenes de MEB. Fotografía 1: Abundantes adherencias con morfologías compatibles con microorganismos sobre una fibra del sudario.

Fotografía 2: Posibles esporas con ornamentación superficial, adheridas a otra fibra de lino. Estas adherencias son un claro indicador de procesos de biodegradación. 
Llama la atención el hecho de que no se han observado partículas de polen, ni siquiera de polen procedente de dispersión eólica. Una posible explicación es que el sudario de León, durante la mayor parte del tiempo, se mantuvo en unas condiciones que lo protegían del exterior, evitando que las partículas de polen, a pesar de su ubicuidad, no pudiesen llegar hasta él (Boi y Sánchez Hermosilla, 2017).
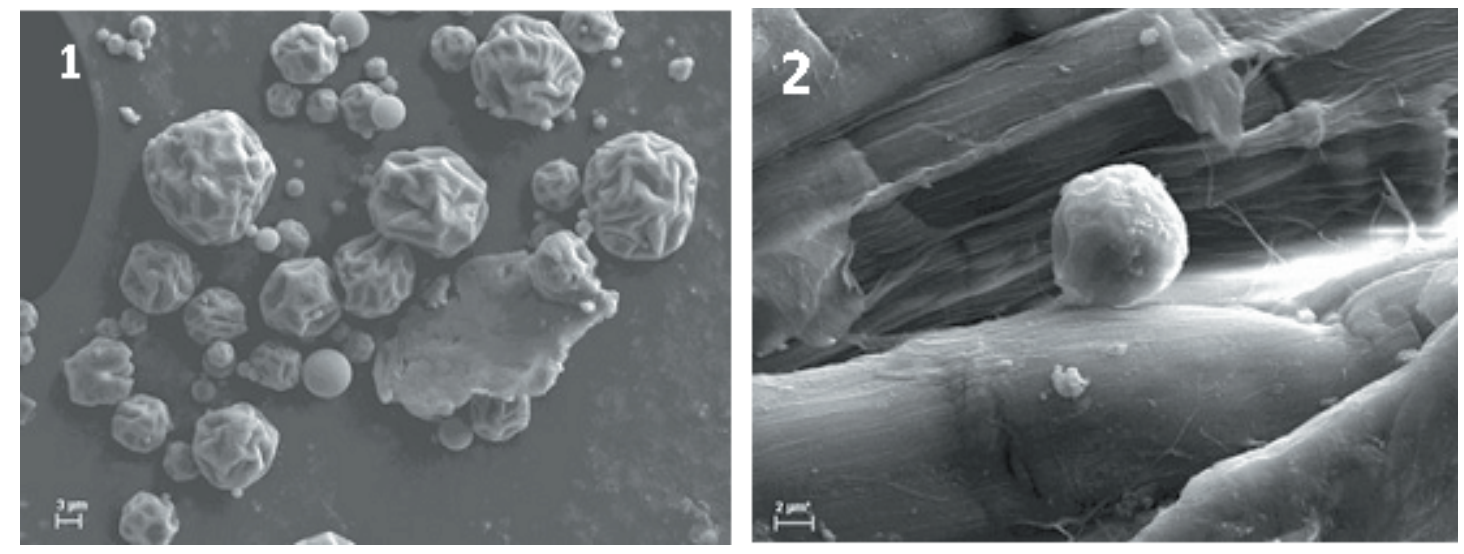

Imagen 33

Vistas con MEB de material ligado al sudario de León. Fotografía 1: Material particulado desprendido, con esporas de superficie rugosa, granos de calcita idiomorfa y partículas esféricas (micrometeoritos o cenizas volantes de centrales térmicas). Fotografía 2: Espora con morfología umbilicada adherida a una fibra de lino; detrás, observamos posibles hifas de hongos sobre otra fibra de lino.
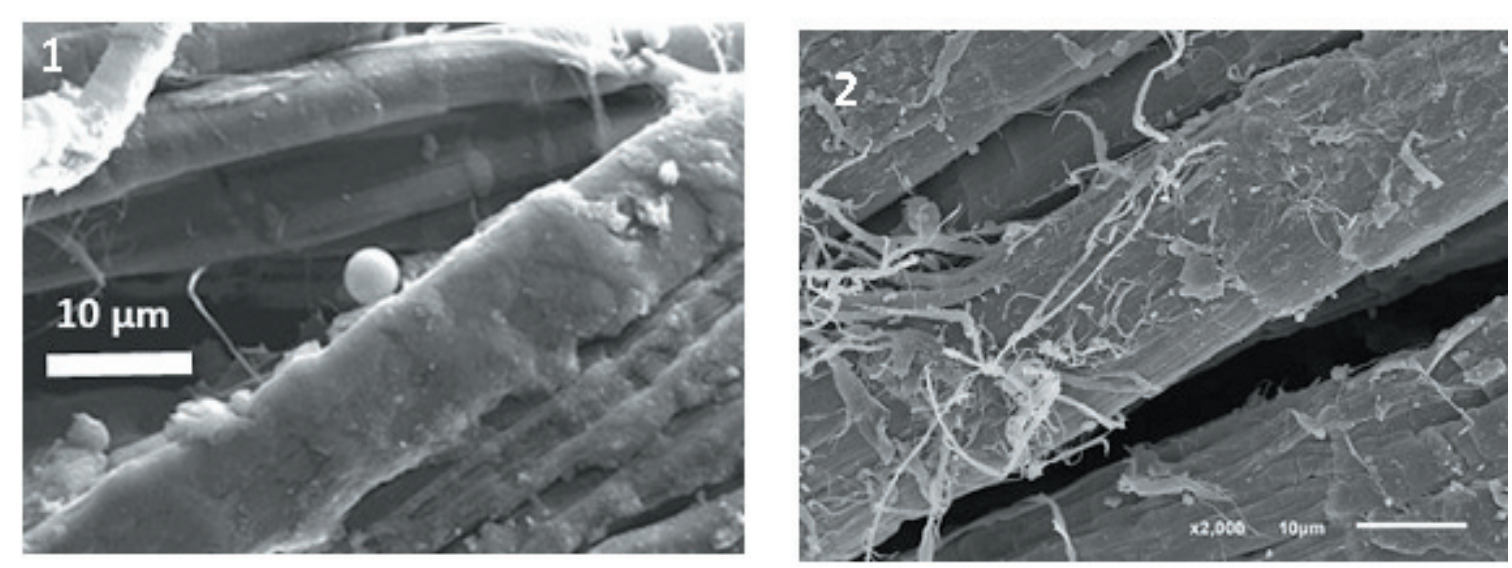

Imagen 34

Observación con MEB de los efectos del biodeterioro sobre fibras de lino del sudario de León.

Fotografía 1: Fibras recubiertas con biocostra, y con partículas adheridas (se aprecia una de morfología esférica). Fotografía 2: Fibras corroídas y con escasa biocostra (aparece en la parte derecha de las fibras), que muestran cómo se despegan tiras de haces de fibrillas.

La presencia de material biológico compatible con bacterias y hongos es coherente con los resultados de la investigación sobre otros lienzos antiguos, como por ejemplo el Sudario de Oviedo (Monte López, 1994). Parece juicioso aconsejar, de cara a su conservación, evitar la proliferación de dichos microorganismos sometiendo al lienzo a unas condiciones de conservación más adecuadas. 


\subsection{Material orgánico de procedencia humana}

También ser realizó un estudio sobre la posible presencia de material biológico de origen humano, que confirme o desmienta el uso del sudario de León como lienzo funerario en algún momento; así como sobre la contaminación procedente de otros seres humanos que hayan podido manipular el material objeto de estudio a lo largo de la historia. Dicho estudio se realizó sobre pequeñas muestras de tejido tomas de la zona 5b (imagen 1) y se llevó a cabo tanto en las dependencias de la Universidad de Oviedo, como en las de la Universidad Católica San Antonio (UCAM) de Murcia.

Las manchas debidas a lo que parecían ser fluidos cadavéricos no mostraron la presencia de elementos celulares sanguíneos; algo esperable, pues la sangre cadavérica suele estar hemolizada, y las membranas celulares, con el paso del tiempo, se suelen dañar hasta quedar prácticamente irreconocibles. Sin embargo, la morfología macroscópica y microscópica de dichas manchas, así como su análisis atómico, mostró que sí son compatibles con estar causadas por fluidos cadavéricos. Aunque su presencia es escasa en el sudario de León. En estas manchas se observa que los fluidos impregnaron los hilos del tejido, ligando fuertemente las fibras de lino (imágenes 35 y 36).
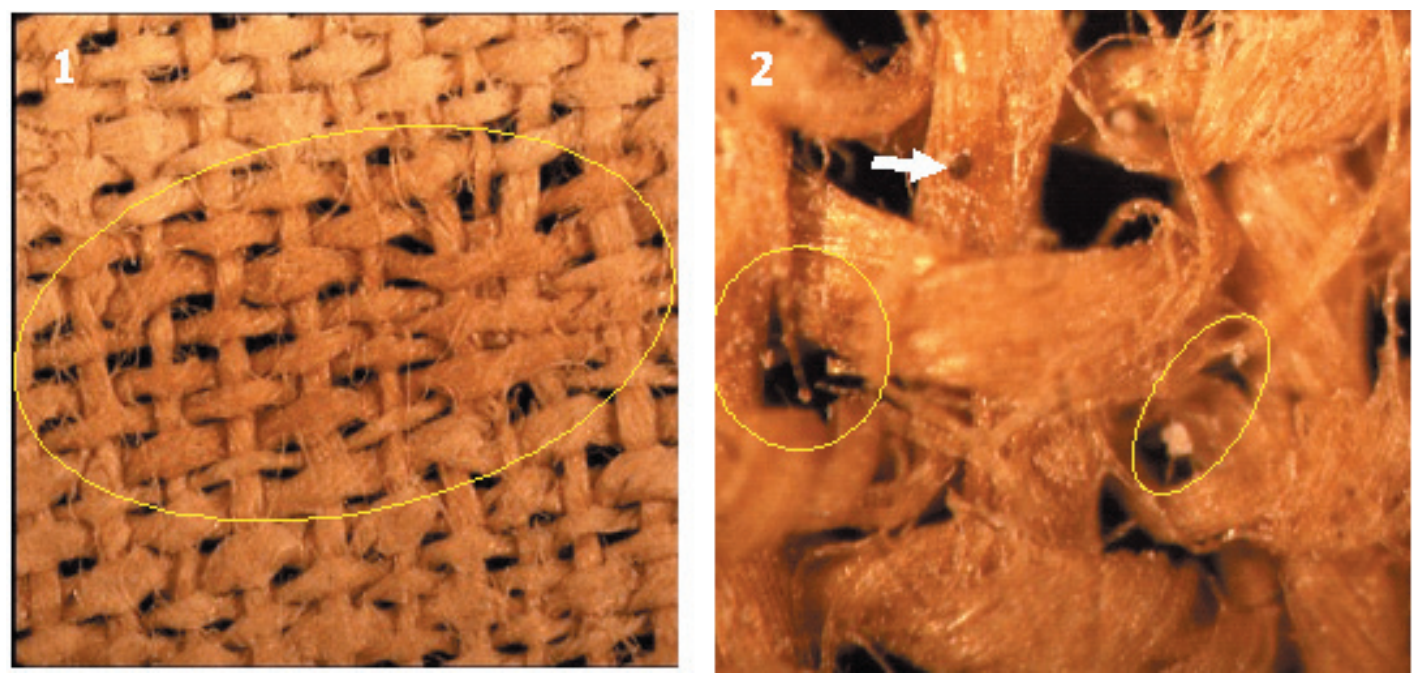

Imagen 35

Microscopio binocular con iluminación episcópica. Fotografía 1: Mancha de contorno elíptico, compatible por su forma y color con goteo de fluido cadavérico sobre el tejido ligeramente inclinado. Fotografía 2: Hilos impregnados por el fluido, con partículas oscuras compatibles con mayor carga hemática (flecha), y con microcristales de sal adheridos a las fibras (evidentes en las zonas delimitadas en la fotografía 2).

También se buscaron de forma activa productos naturales o de síntesis que pudieran haber sido utilizados para embalsamar o conservar el posible cadáver, o con los que pudiera haber estado en contacto el material textil, destinados a un uso funerario, pero sin éxito. Esta ausencia, en sí misma, no excluye la hipótesis de que 
el sudario de León hubiese podido ser usado para amortajar un cadáver, también pudo usarse para contener restos esqueléticos desprovistos de partes blandas, en cuyo caso, ya no era necesario el uso de estos productos. También cabe la posibilidad de que en ningún momento embalsamaran ni emplearan ningún producto para su conservación (Díez, 1994).
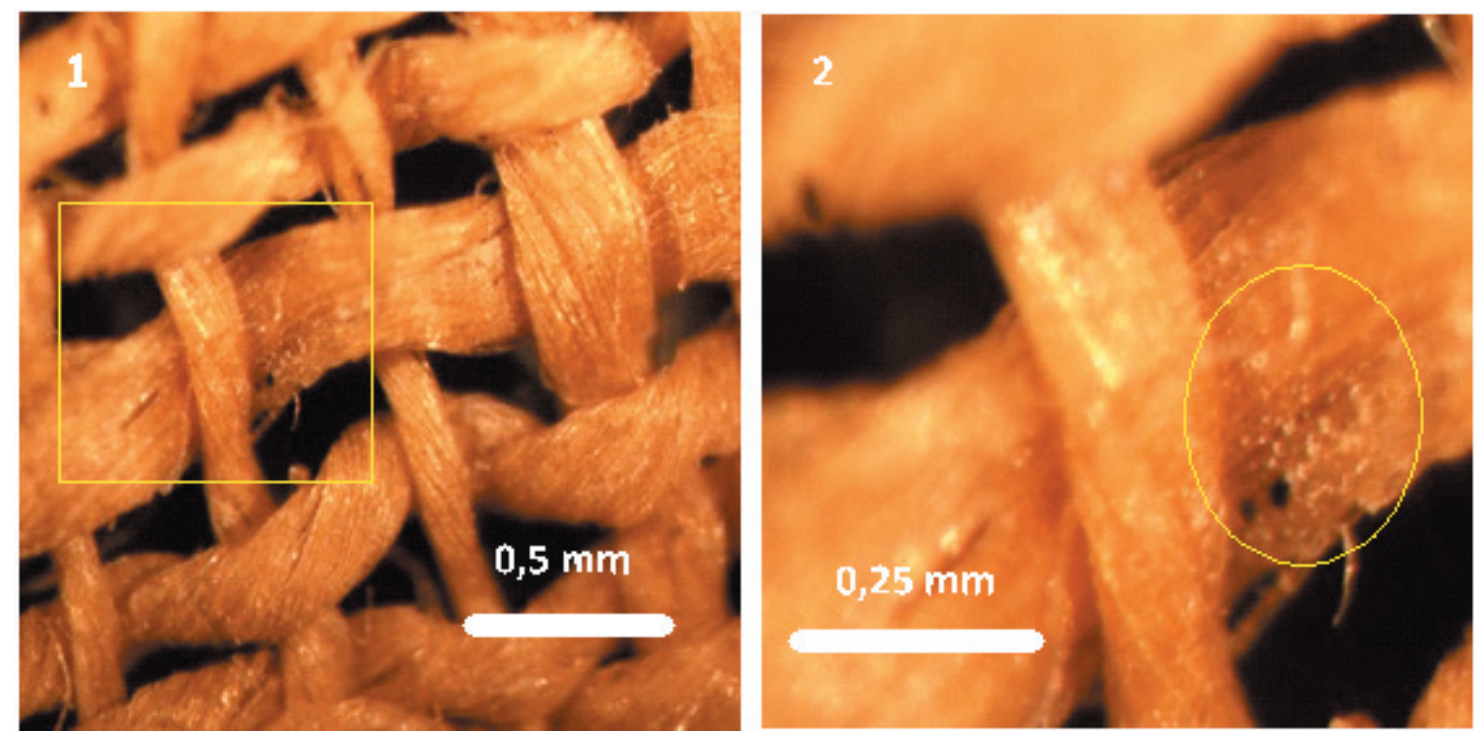

Imagen 36

Otro ejemplo de hilos impregnados por posible fluido cadavérico y con fibras muy ligadas.

Fotografía 1: Se observan partículas oscuras y microcristales de sal.

Fotografía 2: Ampliación del recuadro de la fotografía 1; la elipse delimita una zona donde se observan dos partículas oscuras y numerosos cristales de sal adheridos.

Tampoco está descrito en la bibliografía que se usasen productos conservadores sobre restos humanos esqueletizados en ese entorno geográfico, histórico y antropológico en concreto. Debe señalarse que pasado el tiempo necesario, habitualmente un año en las condiciones climáticas de Oriente Medio, solían recogerse los restos óseos del cadáver, se colocaban dentro de un osario, habitualmente tallado en roca caliza, y se enterraba todo el conjunto de forma definitiva (Díez, 1994).

El estudio paleotanatológico aportó una información muy relevante sobre el uso o usos a que pudo estar destinado el material textil en el pasado. Este análisis sería relevante, incluso en el caso de que no se detecte material biológico de origen humano, pues esta ausencia de información, por sí sola, no descartaría su uso como sudario en el pasado.

Los resultados del estudio de las manchas de lo que parecían ser fluidos cadavéricos resultan compatibles con la hipótesis de que sea ese su origen: tanto la morfología de las manchas, como la composición atómica de las mismas orientan hacia esa posibilidad.

90 Con los medios actualmente disponibles, es de esperar que los resultados del estudio genético del material de estas manchas sea poco determinante, dada la 
ausencia de elementos celulares dotados de núcleo celular; lo que conlleva escasa presencia de material genético y un elevado nivel de contaminación añadida, así como la más que probable presencia de inhibidores de ADN. Todo ello hace juicioso esperar a que los medios técnicos mejores, antes de emprender estudios genéticos, si se considerasen necesarios.

\subsection{Reflexiones finales sobre el material inorgánico hallado}

Como se ha expuesto, resulta muy escasa la presencia de partículas minerales provenientes del polvo ambiental local. Lo que parece indicar que el tejido se mantuvo aislado en algún espacio cerrado o en un contenedor que lo protegía, y en el que se conservó plegado. La ausencia de polen observada podría obedecer a esta misma razón.

El análisis químico hecho con la sonda del MEB de muestras procedentes de las Zonas 5 a y 5b (imagen 1), confirmó la presencia abundante de partículas de carbonato cálcico, cloruro sódico, cuarzo y alumino-silicatos. El carbonato cálcico detectado no corresponde a polvo de roca caliza, sino principalmente a granos constituidos por microcristales de calcita idiomorfa y autóctona, formada sobre el tejido a partir de la contaminación con cal.

Las características exoscópicas (redondez y esfericidad elevadas, así como abundantes huellas de impacto) de granos de cuarzo que fueron precozmente incorporados al sudario -son los granos encontrados en el interior del doblez y los englobados en las manchas de cal-, señalan que estos granos proceden de un ámbito en el que fueron sometidos a transporte y deposición eólicos (Krinsley Donahue, 1968; Campbell, 1963). También se han encontrado algunos granos de travertino (CO3Ca) afectado de pulido eólico (ver imagen 37), los cuales, dada su baja dureza
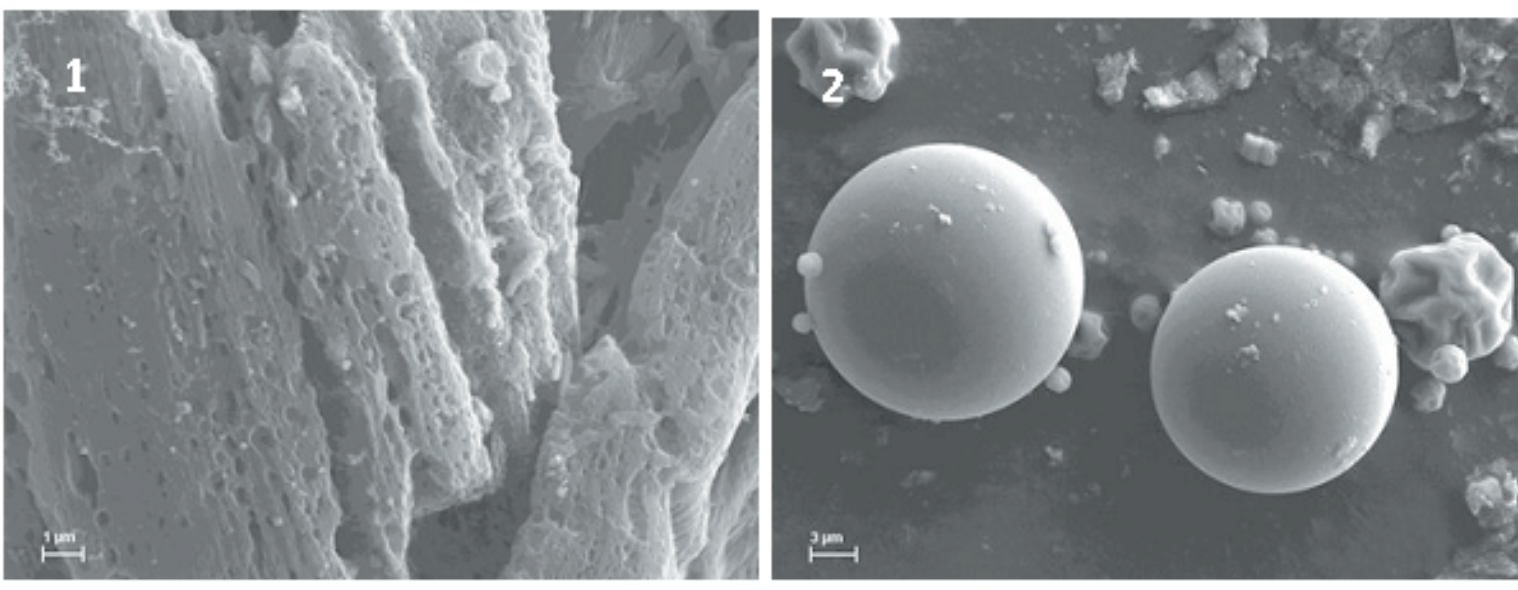

Imagen 37

Partículas minerales contaminantes del sudario, vistas con MEB. Fotografía 1: Partículas de carbonato cálcico con textura de travertino y superficies con pulido eólico. Fotografía 2: Partículas esféricas de posibles cenizas volantes o polvo extraterrestre (micrometeoritos). 
y su débil resistencia al desgaste, procederían necesariamente de una fuente no lejana. Estos datos resultarían compatibles con una localización del Sudario en un área de climatología desértica, dentro de la cual habría sido confeccionado y en la que habría permanecido durante un tiempo.

$94 \quad$ Un hallazgo esperado fue la presencia de partículas esféricas de composición silicatada, que resultan compatibles con polvo de origen extraterrestre (micrometeoritos), o con cenizas volantes procedentes de centrales térmicas que queman carbón (imagen 37). Estas esferas son componentes muy ubicuos del polvo atmosféri$\mathrm{co}$, que se encuentran en cualquier punto de la superficie terrestre, incluido el polvo que se decanta en nuestros domicilios.

95 También se verificó la presencia de sílice, componente habitual de cualquier contaminación con polvo de tejidos, antiguos o actuales, y en cualquier área geográfica. Gracias al estudio con microscopía óptica, hemos determinado dos morfologías diferenciadoras de dos poblaciones distintas: una la constituyen los granos de cuarzo redondeados, que sufrieron un transporte y pulido eólico y que representan granos de arena procedentes de un área desértica; la otra está constituidas por las partículas angulosas de cuarzo debidas a fragmentación mecánica, que se habrían generado por la excavación en roca silícea de un hueco (posible tumba), y que quedarían como componente principal del polvo interior, sin sufrir transporte ni redondeamiento alguno (imagen 29).

96 Los granos de cuarzo eólico los encontramos tanto en el interior del dobladillo como cementados en las placas de lechada de cal; y también como componentes de la partícula de suelo estudiada. Lo que nos indica que tanto el taller en el que se confeccionó el sudario, como el lugar de fabricación de la lechada de cal con que se contaminó la tela, estaban localizados en un área desértica. Y también pertenecería a un área desértica el fragmento de suelo que se incorporó al sudario. En cambio, los fragmentos angulosos de cuarzo cementados en la lechada de cal nos indican que ese cuarzo fue incorporado en el interior del hueco, al caer gotas de cal sobre el tejido plegado y horizontal, y al integrar partículas del polvo interior depositado sobre el propio tejido. Este dato probaría que la cal se incorporó al tejido dentro del posible sepulcro, no anteriormente; y por las características de las manchas de cal, sabemos que, además, el lienzo estaba plegado y en posición horizontal.

97 Por su parte, los cristales de sal común presentes en el sudario de León (imágenes 35 y 36), son el fruto de un proceso de condensación-evaporación del agua atmosférica, como consecuencia de fuertes oscilaciones térmicas noche-día, en el interior del hueco donde está situado. Los microcristales de $\mathrm{NaCl}$ son componentes comunes en telas de lino antiguas procedentes de enterramientos. Esta sal es también un claro indicador de que el lienzo residió en un hueco subterráneo localizado en un ámbito desértico.

Gran parte de las características descritas, en especial las referentes a la biodegradación presentes en hilos y fibras del sudario de León, son compatibles con las observadas en el Sudario de Oviedo (Montero Ortego, 1994 y 2007). 


\subsection{Sobre la biodegradación y la datación con C14}

Hasta ahora, el protocolo seguido para la limpieza de telas sometidas a datación mediante el C14 da por hecho que la eliminación de contaminantes es completa. Pero hay sospechas fundadas de que eso no es así. Nosotros hemos verificado con fibras de lino del Sudario de Oviedo que la eliminación de biocostras no es completa, cuando se someten esas fibras al protocolo de limpieza establecido.

En este estudio hemos mostrado que las fibras del sudario de León presentan un estado de biodegradación con buen desarrollo de biocostras, análogo al que hemos encontrado en el Sudario de Oviedo. Estos restos de biodegradación, que poseen mayor proporción de C14/C12 que las fibras de lino sobre las que se encuentran, si no fuesen eliminados completamente antes de la datación mediante el C14, motivarán una edad radiocarbónica de la tela más joven de la que le corresponde. Y esta es una objeción que cabe hacer a cualquier datación radiocarbónica de telas antiguas hecha hasta el presente, en la que no conste una verificación del grado de limpieza de la contaminación por biodegradación (Cabrera Lafuente y Rodríguez Peinado, 2007).

101 Por otro lado, los procesos de limpieza previos al análisis radiocarbónico de telas de lino, frecuentemente se constata fuerte disolución del material constituyente de las fibras, en las que las fibrillas de celulosa resultan más resistentes que la lignina cementante. Este hecho puede ser también causa de una modificación al alza en la proporción C14/C12 que le correspondería a una fibra no afectada. En la foto derecha de la imagen 34 observamos fibras de lino del sudario de León que muestran importante corrosión por disolución de la lignina que liga los haces de fibrillas; corrosión que es consecuencia del proceso de biodegradación sufrido, y que facilita el desgajamiento de haces de fibrillas. Un efecto similar de corrosión se produce cuando se someten fibras actuales de lino a procesos industriales de mercerización, buscando ese mismo efecto para poder concentrar la celulosa.

Tanto la disolución de lignina cementante durante el lavado del tejido previo a la datación con C14, como la limpieza incompleta de material orgánico derivado de la biodegradación, pueden motivar un "rejuvenecimiento" del tejido. Por lo que cualquier datación radiocarbónica de tejidos de lino debe verificar estos aspectos -lixiviación intensiva de lignina frente a la celulosa y eliminación incompleta de biocostras-, antes de validar los resultados obtenidos. Una datación sin esa verificación resultaría siempre sospechosa. Como sabemos, muchos arqueólogos prefieren actualmente usar criterios arqueológicos de datación, relativizando el valor absoluto de la datación radiocarbónica.

Dada la semejanza entre el estado de biodegradación de este sudario de León y el que encontramos en el Sudario de la Catedral de Oviedo, resultaría interesante cotejar los resultados de análisis con C14 de ambos lienzos, hipotéticamente coetáneos. El sudario de Oviedo, por dos veces, nos ha dado edad radiocarbónica del siglo VII; y el hipotético desvío de su edad real estaría ligado, al menos en parte, a los dos efectos anteriormente considerados: eliminación no completa de la biocos- 
tra ligada a las fibras de lino (hecho constatado por nosotros experimentalmente); y disolución elevada de materia fibrilar (constatado por el laboratorio que realizó la datación), que podría implicar una eliminación más intensa de los componentes ligantes (lignina) frente a las fibrillas de celulosa.

\section{CONCLUSIONES}

El Sudario del Museo Bíblico de León es una pieza textil de notable valor, dada su antigüedad, dimensiones y estado de conservación. Está confeccionado en lino, tejido de forma manual en un telar vertical, bastante más largo que alto. Los hilos, que también fueron hilados a mano, presentan torsión en $\mathrm{S}$.

105 Los rasgos singulares del tipo de nudos usados en hilos de trama, con los cabos fuertemente enrollados sobre el hilo, muestran un trabajo extra sistemático del tejedor/a, conducente a mantener ocultos esos cabos y darle mayor calidad al tejido.

106 Los remates con dobladillo de gran calidad en los bordes izquierdo y derecho del sudario, así como el remate con flecos del borde inferior, son también pruebas de que no nos hallamos ante un simple tejido destinado a fines funerarios; sino que se trata de una pieza cuidadosamente rematada, destinada a servir como prenda de uso personal. La conclusión que parece más lógica es que se trata de una prenda tipo chal, mantón o similar que, finalmente, se usó como componente del complejo funerario de un enterramiento, con una finalidad discutible.

107 La ausencia, tanto en hilos de urdimbre como de trama, de fibras contaminantes de origen animal (lana, pelo de cabra o pelo de camello) resultan compatibles con la hipótesis de que el sudario se tejiese en un telar judío; o que, si no era judío, estaba destinado a ser vendido en este mercado; y, por ello, se respetaron las escrupulosas normas de pureza ritual, es decir, no mezclar fibras animales y vegetales en un mismo tejido. Las fibras de lana encontradas son contaminantes añadidos ajenos al proceso de hilado y tejido del sudario.

108 Se trata de un objeto descontextualizado del que se desconoce su procedencia concreta. Los hallazgos sobre los efectos de la biodegradación sufrida resultan compatibles con los obtenidos en el estudio del Sudario de Oviedo. Y la existencia en el mismo museo de León de otros objetos confeccionados en material textil, y datados entre finales del siglo I a.C. y principios del siglo I d.C. hacen creíble la hipótesis de que el Sudario de León puede tener la cronología que se le asigna (siglo I).

109 La ausencia de partículas de polen, así como la presencia relativamente escasa de partículas minerales contaminantes en la superficie del tejido, resultan compatibles con la hipótesis de que el Sudario de León se ha conservado en unas condiciones de aislamiento que le han protegido en el pasado de estas contaminaciones.

110 Los hallazgos expuestos en este trabajo resultan compatibles con la hipótesis de que, aunque posiblemente el sudario de León fue fabricado para ser usado co- 
mo prenda personal, finalmente pudo habérsele dado un uso funerario, que justificaría la contaminación con posibles fluidos cadavéricos.

La ausencia de áloe, mirra, y otros productos que, según la bibliografía disponible, solían usarse con fines funerarios en la Palestina del siglo I, nos llevan a la conclusión de que el sudario de León no fue empleado como mortaja de un cadáver. Pero las manchas que presenta y que resultan compatibles con fluidos cadavéricos nos permiten formular la hipótesis de que esta prenda sí fue usada como complemento funerario en un enterramiento.

112 Los sistemas de pliegues que muestra el sudario revelan que permaneció largo tiempo plegado y horizontal, y que incluso pudo soportar el peso de algún fardo puesto encima.

113 Dado que las manchas se producen estando el lienzo plegado, resulta lógico suponer que este estaba localizado debajo de un cadáver amortajado y envuelto, desde el que le llegaron los fluidos cadavéricos. También cabría suponer que las manchas se producen al depositar encima del sudario plegado los restos esqueletizados de un cadáver; lo que también justificaría la escasa presencia de material biológico compatible con fluidos biológicos humanos; así como la ausencia de áloe, mirra, y otros productos que, según la bibliografía disponible, solían usarse en aquel contexto histórico, geográfico y antropológico para amortajar los cadáveres, pero que, al parecer, no se usaban sobre los restos humanos ya esqueletizados.

114 El estudio de las partículas minerales contaminantes ligadas al sudario (principalmente cuarzo) muestra que el ámbito en el que este se confeccionó y conservó era un ámbito desértico. También muestra contaminación con esquirlas angulosas de cuarzo, componente característico del polvo generado en la excavación de una cavidad en roca silícea, dentro de la cual habría sido depositado el sudario.

115 La presencia de cristales de sal común adheridos a las fibras de lino, que indica un proceso de condensación-evaporación en una cavidad subterránea localizada en un área de fuertes oscilaciones térmicas, resulta ser otro indicador de área desértica.

Aunque el sudario de León muestra un buen estado de conservación aparente, el estudio hecho nos muestra que está afectado por un evidente proceso de biodegradación, debido a microorganismos colonizadores, que, posiblemente siguen activos. Consecuentemente, parece razonable proponer que, en el futuro, se mejoren las condiciones de conservación del tejido.

117 A tales efectos, el Sudario de León debería conservarse en posición horizontal y extendido, para minimizar los daños mecánicos del mismo. También debería conservarse dentro de algún contenedor que lo mantuviese aislado de las condiciones ambientales (exposición continuada a la luz, cambios de temperatura y de humedad, etc.), así como de cualquier organismo, macroscópico o microscópico, que pudiera dañarlo. Se propone el uso de una teca similar a la que protege el Sudario de 
Oviedo, con atmósfera interior de gas argón, con el fin de limitar el desarrollo y actividad de microorganismos aeróbicos.

118 Con independencia de la propuesta anterior, y para limitar el fotodeterioro del sudario, se aconseja disponer de un cristal que, sin impedir la observación del sudario, permitiese la filtración de luz ultravioleta, que daña el tejido.

También vemos conveniente realizar controles periódicos de las condiciones de conservación, con una periodicidad de entre dos y tres años, prestando especial atención al posible progreso del biodeterioro. La realización complementaria de algún ensayo de cultivo con muestras tomadas directamente del sudario, podría resultar útil, como medio de control de la actividad microbiana.

120 Sería interesante poder datar el Sudario de León. Y aunque el método de Radiocarbono 14 ofrece reservas en el caso de telas antiguas, consideramos que sería interesante un estudio comparado con el Sudario de la Catedral de Oviedo, dado el paralelismo existente entre ambos tejidos, en especial su grado de biodegradación y su consideración de tejidos del siglo I.

121 El posible material biológico de probable origen humano podría ser investigado en el futuro, cuando los métodos analíticos paleogenéticos estén más desarrollados técnicamente.

\section{BIBLIOGRAFÍA}

BOI, M. y SÁNCHEZ HERMOSILLA A. (2017), "Pollens on the Shroud of Turin and the Sudarium of Oviedo", The International Conference on the Shroud of Turin (ICST-2017), Pasco, Washington, July 19 to 22, 2017.

CABRERA LAFUENTE, A. y RODRÍGUEZ PEINADO, L. (2007), “La datación de C-14 aplicadas a tejidos: el caso de las manufacturas coptas", Actas del II Congreso Internacional sobre el Sudario de Oviedo, Oviedo, 13 al 15 de abril de 2007, 663-673.

CAMPBELL, D. H. (1963), "Percussion marks on quartz grains", Journal of Sedimentary Petrology, vol. 33, No. 4, 855-859.

DÍEZ, F. (1994), "Ritos Funerarios Judíos en la Palestina del s. I", Sudario del Señor. Actas del I Congreso Internacional sobre el Sudario de Oviedo, Universidad de Oviedo, Oviedo, 29, 30 y 31 de octubre de 1994, 273-283.

GARCÍA IGLESIAS, J., ÁLVAREZ GARCÍA, R. y GARCÍA ALONSO J. I. (2007), “Valoración y crítica de técnicas aplicables al estudio y correlación de tejidos de interés arqueológico", Actas del II Congreso Internacional sobre el Sudario de Oviedo, Universidad de Oviedo, Oviedo, 13 al 15 de abril de 2007, 177-228.

GÓMEZ FERRERAS, C. (1994), "El Sudario de Oviedo y la Palinología", Actas del I Congreso Internacional sobre el Sudario de Oviedo, Universidad de Oviedo, Oviedo, 29, 30 y 31 de octubre de 1994, 83-90.

IRIARTE CHIAPUSO, M. J. (2007), "Sudario de Oviedo y Palinología”, Actas del II Congreso Internacional sobre el Sudario de Oviedo, Oviedo, 13 al 15 de abril de 2007, 125-134. 
KRINSLEY, D. H. y DONAHUE, J. (1968), “Environmental interpretation of sand grain surface textures by electron microscopy", Geol. Soc. of Am. Bull., 79, 743-748.

MONTE LÓPEZ, E. (1994), "Estudio Micológico del Sudario de Oviedo", Actas del I Congreso Internacional sobre el Sudario de Oviedo, Universidad de Oviedo, Oviedo, 29, 30 y 31 de octubre de 1994, 91-94.

MONTERO ORTEGO, F. (1994), “Sudario de Oviedo. Descripción química y microscópica. Elementos encontrados", Actas del I Congreso Internacional sobre el Sudario de Oviedo, Universidad de Oviedo, Oviedo, 29, 30 y 31 de octubre de 1994, 67-82.

- (2007), "Descripción química y microscópica del lienzo", Actas del II Congreso Internacional sobre el Sudario de Oviedo, Oviedo, 13 al 15 de abril de 2007, 103-124. 